\title{
Coupling textural and stable-isotope variations in fluvial stromatolites: Comparison of Pleistocene and recent records in NE Spain
}

\author{
C. Arenas ${ }^{1,2^{*}}$, M. C. Osácar ${ }^{1,2}$, L. Auqué ${ }^{\text {and C. Sancho }}$
}

\begin{abstract}
Textural and stable isotopic features of two middle Pleistocene fluvial stromatolite profiles are compared to a recent stromatolite, both formed in the River Piedra system (NE Spain), to test the reliability of climatic, hydrologic and depositional information derived from ancient records. The Pleistocene stromatolites formed in a multi-domed, highly-inclined cascade-barrage. The recent stromatolite also formed in a highly-inclined cascade of the River Piedra, the sedimentary conditions of which were periodically examined between the years 2000 and 2012.

The Pleistocene stromatolites are formed of an alternation of 1) thin large-crystal laminae (type A), with elongated crystals up to $1 \mathrm{~mm}$ long, and 2) thick small-crystal laminae (type B), consisting of cyanobacterial fan- and bushshaped bodies. The textural and isotopic comparison with the recent stromatolite shows that each A-B couplet corresponds to one year. The type-A laminae are comparable to the macrocrystalline laminae that occur in the cool-period deposits of the recent stromatolite, and the type-B laminae are comparable to the warm-period deposits of the recent stromatolite.

Water temperatures $(T w)$, calculated from $\delta^{18} \mathrm{O}_{\text {calcite }}$ and present measures of $\delta^{18} \mathrm{O}_{\text {water, }}$ were similar in the Pleistocene and recent specimens, and close to the measured river Tw. Thus, the Pleistocene stromatolites formed not far from isotopic equilibrium, as did the recent stromatolite. The Pleistocene $\delta^{18} \mathrm{O}_{\text {calcite }}$ biannual oscillation is wider in amplitude than in the recent stromatolite, which suggests larger differences in Tw through the year in the Pleistocene than at present. The Pleistocene $\delta^{13} C_{\text {calcite }}$ does not show any pattern; and the values are slightly higher than the recent ones. The co-evolution of $\delta^{18} \mathrm{O}$ and $\delta^{13} \mathrm{C}$ is parallel in the Pleistocene stromatolites, matching the recent stromatolite behavior.

These results and their comparison with other ancient examples prove that textural and isotopic features in ancient stromatolites are useful tools to infer past depositional, climatic and hydrological conditions. Moreover, interpretations from recent fluvial stromatolites can be extrapolated to past environments to help decipher patterns of past processes, in cases where both recent and ancient stromatolites can be compared within one environmental setting. Such comparisons may be used to help interpretations of ancient stromatolites where the modern ones are not available to study.
\end{abstract}

Keywords: Tufa, Recent and ancient stromatolites, Stable isotopes, Biotic and abiotic laminae, Intra-annual and inter-annual water temperature variations

\footnotetext{
* Correspondence: carenas@unizar.es

${ }^{1}$ Department of Earth Sciences, University of Zaragoza, 50009 Zaragoza, Spain

${ }^{2}$ Geotransfer Group and Institute for Research on Environmental Sciences of

Aragón (IUCA), 50009 Zaragoza, Spain
} 


\section{Introduction}

Stromatolites are laminated structures considered to be biogenically formed or at least related to biogenic processes (e.g., Kalkowsky 1908; Riding 2000). In some present-day calcareous streams and lakes, cyanobacterial calcification is well-developed and is significantly involved in the formation of tufas (Golubic 1976; Pentecost 1978; Pedley 1990; Riding 2000). Tufas are formed by calcium carbonate precipitation on diverse aquatic biota in ambient-temperature water that is charged with meteoric $\mathrm{CO}_{2}$ producing a great variety of sedimentary facies and structures (Arp 1995; Arenas-Abad et al. 2010). Stromatolites may thus occur in flowing-water environments associated with carbonate bedrocks and aquifers (Ford and Pedley 1996; Pentecost 2005). These "tufa stromatolites" (cf. terminology of Riding 2000) can form extensive and thick deposits in present-day and Quaternary fluvial environments. They are largely produced by encrustation of the sheath (Merz-Preiß and Riding 1999), i.e. by mineral precipitation on the organic tissue (Riding 1991). This is the main difference with respect to skeletal stromatolites (Riding 2000).

Tufas can register environmental conditions and their changes, therefore they have been used as records of palaeoenvironmental change (Andrews 2006; Capezzuoli et al. 2014). Texture provides information on the sedimentation context of the tufa formation. Particularly, in tufa stromatolites, the lamination allows annual resolution of the environmental signature (Kano et al. 2007; Arenas and Jones 2017; Rodríguez-Berriguete et al. 2018). In addition, stable isotopes can provide significant information about climate parameters on different time scales and, at times, even quantitative variations of seasonal temperature, via the ${ }^{18} \mathrm{O} /{ }^{16} \mathrm{O}$ fractionation. As for the $\delta^{13} \mathrm{C}_{\text {calcite, }}$ it reflects, among other parameters, the relative contribution of organic carbon, which can depend on biota development and water availability (Andrews 2006). Nevertheless, the diversity of factors that are involved in the tufa isotopic signature makes it difficult to extract palaeoenvironmental information from fossil tufa (Lojen et al. 2004; Anzalone et al. 2007; Rodríguez-Berriguete et al. 2018).

Monitoring of the present-day processes of tufa formation has often become a useful resource to assess the relationship between tufa formation and the involved environmental parameters (Manzo et al. 2012; Osácar et al. 2016 and references therein). However, the application of the information derived from present-day tufas to decipher the formation conditions of fossil tufas is not straightforward. As a matter of the fact, tufas deposited under the same climate conditions may show different textural and isotopic responses depending, for instance, on the hydrodynamic conditions of the sedimentary environment, e.g., distance to the springs and deposition in ramp- vs pool-environments (D'Argenio and Ferreri 1988; Wang et al. 2014). Therefore, this study aims to help constrain the interpretation of the formation of ancient tufa stromatolites features by directly comparing them with present tufa stromatolites formed in the same environmental setting. The results are compatible with studies in some ancient fluvial and lacustrine records, and may therefore be used to help develop a greater understanding of environmental processes affecting tufas in the rock record.

Several valleys in the Iberian Ranges (northeastern part of the Iberian Peninsula, Fig. 1a) contain tufa deposits that formed during the Quaternary (Peña et al. 2014; Sancho et al. 2015). At present, tufa formation continues in several of the river courses due to $\mathrm{Ca}^{2+}$ - and $\mathrm{HCO}_{3}{ }^{-}$-rich water supply from karstic aquifers hosted in the Mesozoic thick carbonate-rock sequences (Vera 2004). The River Piedra valley (the Spanish word piedra means stone) hosts thick and extensive Quaternary tufas that have been the focus of several studies (Vázquez-Urbez et al. 2011, 2012; Sancho et al. 2015). Moreover, at present, a prominent feature of this river is the presence of a large tufa formation, which has allowed periodic monitoring over 13 years in the Monasterio de Piedra Natural Park, an excellent site for present tufa formation (e.g., Vázquez-Urbez et al. 2010; Arenas et al. 2010, 2014; Osácar et al. 2013, 2016).

In this paper representative samples of middle Pleistocene stromatolite tufa collected from the River Piedra area are compared with present-day tufa stromatolites formed in similar conditions in the same river. This recent record formed from 2000 to 2012 on an artificial substrate in the Natural Park, where environmental conditions were known (Arenas et al. 2014; Osácar et al. 2016).

The results underscore the importance of coupling textural features and stable isotope composition in interpreting the temporal and climate significance of stromatolite lamination. More importantly, they show that ancient and recent stromatolites are comparable, both for the textural and isotopic characters. Therefore, the findings from modern stromatolite monitoring can be used, to some extent, to obtain palaeoenvironmental information in ancient stromatolites formed in the same conditions.

\section{Geological setting}

The studied deposits formed in the River Piedra valley, in the central part of the Iberian Ranges (Fig. 1a, b), an intra-plate, NW-SE trending, mountain chain in the northeast of the Iberian Peninsula. In the study area the diverse geological units include: Ordovician sandstones, 


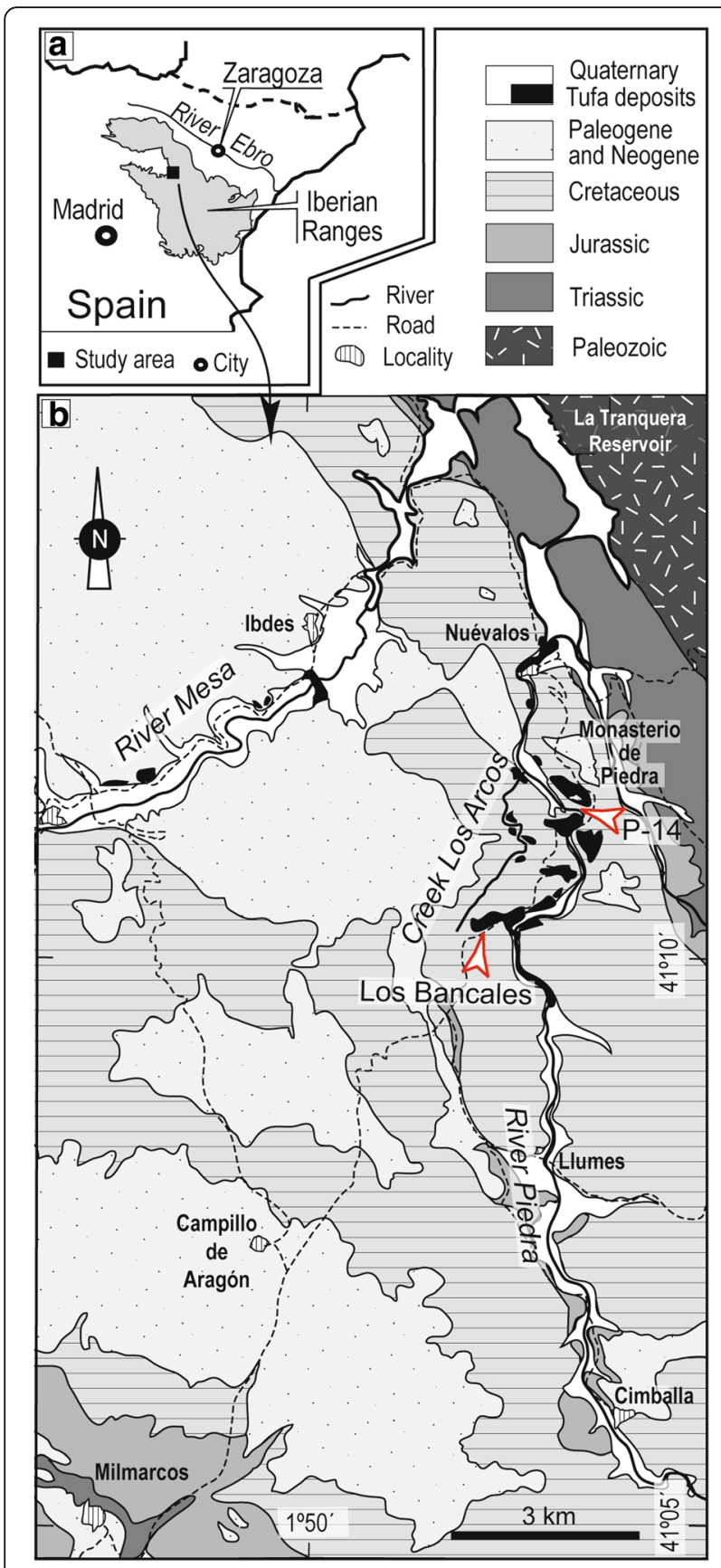

Fig. 1 Geographical location and geological map of the study area. Note in $\mathbf{b}$ the location of the studied stromatolites: Pleistocene deposits at Los Bancales and the modern P-14 stromatolite in the Monasterio de Piedra Natural Park. Paleozoic (Ordovician): Siliciclastic sandstones and mudstones, and quartzites; Triassic: Siliciclastic conglomerates, sandstones and mudstones (Buntsandstein Facies), dolostones and marls (Muschelkalk Facies), and marls and gypsum (Keuper Facies); Jurassic: Dolostones; Cretaceous: Sandstones and mudstones (Albian), and limestones, dolostones and marlstones (Upper Cretaceous); Paleogene and Neogene: Polymict conglomerates, sandstones and mudstones; Quaternary: Gravels, sands and silts, and tufas mudstones and quartzites; Triassic conglomerates, sandstones and mudstones (Facies Buntsandstein), dolostones and marls (Facies Muschelkalk) and mudstones and gypsum (Facies Keuper); Jurassic dolostones; Upper Cretaceous sandstones and mudstones (Albian), and limestones, dolostones and marlstones. The Cenozoic is represented by Paleogene and Neogene alluvial and fluvial conglomerates, sandstones and mudstones. Tufa and associated detrital Pleistocene and Holocene deposits crop out along the river valley, with the thickest deposits in the middle-lower reach, close to the Natural Park (Peña et al. 2014; Sancho et al. 2015). The main carbonate sequences involved in the aquifer that feeds this and other tufa-depositing rivers in the Iberian Ranges are the Middle Jurassic limestones and Upper Cretaceous limestones and dolostones.

\subsection{The present-day carbonate system}

The modern River Piedra is an indirect tributary of the River Ebro that flows from south to north across the Iberian Ranges (northeastern Iberia) (Fig. 1a, b). Close to its entrance into the La Tranquera reservoir, the overall river slope increases and forms a series of cascades, e.g., approximately $15-35 \mathrm{~m}$ high in the Monasterio de Piedra Natural Park (Fig. 1b). Present-day tufa formation becomes noticeable $8 \mathrm{~km}$ downstream of the main springs located at Cimballa (Fig. 1b) and greatly increases coinciding with the main breakpoints in the river profile. Mean water discharge was $1.05 \mathrm{~m}^{3} / \mathrm{s}$ from 1999 to 2012 (data from Confederación Hidrográfica del Ebro, compiled by Arenas et al. 2014). The river water is of the $\mathrm{HCO}_{3}-$ $\mathrm{SO}_{4}-\mathrm{Ca}$ type. Within the park, where the deposit selected for this study formed, alkalinity varied mostly from $228 \mathrm{mg} / \mathrm{L}$ to $350.3 \mathrm{mg} / \mathrm{L}$, Ca content from 75.1 $\mathrm{mg} / \mathrm{L}$ to $105.3 \mathrm{mg} / \mathrm{L}$ and $\mathrm{pH}$ from 6.9 to 8.8 . Saturation index with respect to calcite was usually higher than +0.7 (Vázquez-Urbez et al. 2010; Arenas et al. 2014).

Results from periodic monitoring of hydrochemical, isotopic and sedimentary parameters (every six-months) at several sites that represent different depositional environments along the river over 13 years (Arenas et al. 2014; Osácar et al. 2016) show that: 1) deposition rates vary from less than $1 \mathrm{~mm} /$ year up to ca. $14 \mathrm{~mm} /$ year, depending on flow conditions; 2) seasonal variations in depositional rates are linked to changes in temperature that affect calcite saturation index of water and the development of aquatic biota through photosynthesizing activity and biomass; and 3) calcite $\delta^{18} \mathrm{O}$ composition records temperature seasonal variations, and calcite $\delta^{13} \mathrm{C}$ composition reflects the rainfall variations that affect the river discharge through aquifer recharge. 
The highest deposition rates are linked to fast flow conditions on moderate- to high-slope substrates where microbial mats are dominant. One of these stromatolite records (P-14), formed in a stepped cascade from 2000 to 2012, is used for comparison with the Pleistocene stromatolites.

\subsection{The Pleistocene stromatolites}

The studied Pleistocene deposits formed in the River Piedra (Fig. 1b), a high-gradient tufa system, mostly consisting of stepped barrage-cascade environments (Vázquez-Urbez et al. 2012). In detail, the studied stromatolites form part of a cascade-barrage body that developed along a small valley between the main channel (River Piedra) and a secondary channel that received water from the main valley only during periods of diffluence. The development of tufa barrages in the main valley overpassed the height of the water divide that separated the main and the secondary valleys (Vázquez-Urbez et al. 2011). Then, a series of small cascade-barrages separated by small pools developed along the small valleys as far as to the secondary valley. This diffluence episode occurred between $192 \pm$ $26 \mathrm{ka}$ and $233 \pm 49 \mathrm{ka}$ ago, according to ages provided by aminoacid racemization in carbonate bioclastic silts and sands corresponding to pool facies (Sancho et al. 2015). In the study site, the deposit consisted of extensive stromatolite deposits and minor moss boundstones formed in a cascade-barrage at the entrance of the secondary valley. The height of this cascadebarrage was up to $5 \mathrm{~m}$ and it extended along tens of meters (Fig. 2). The studied stromatolites are roughly

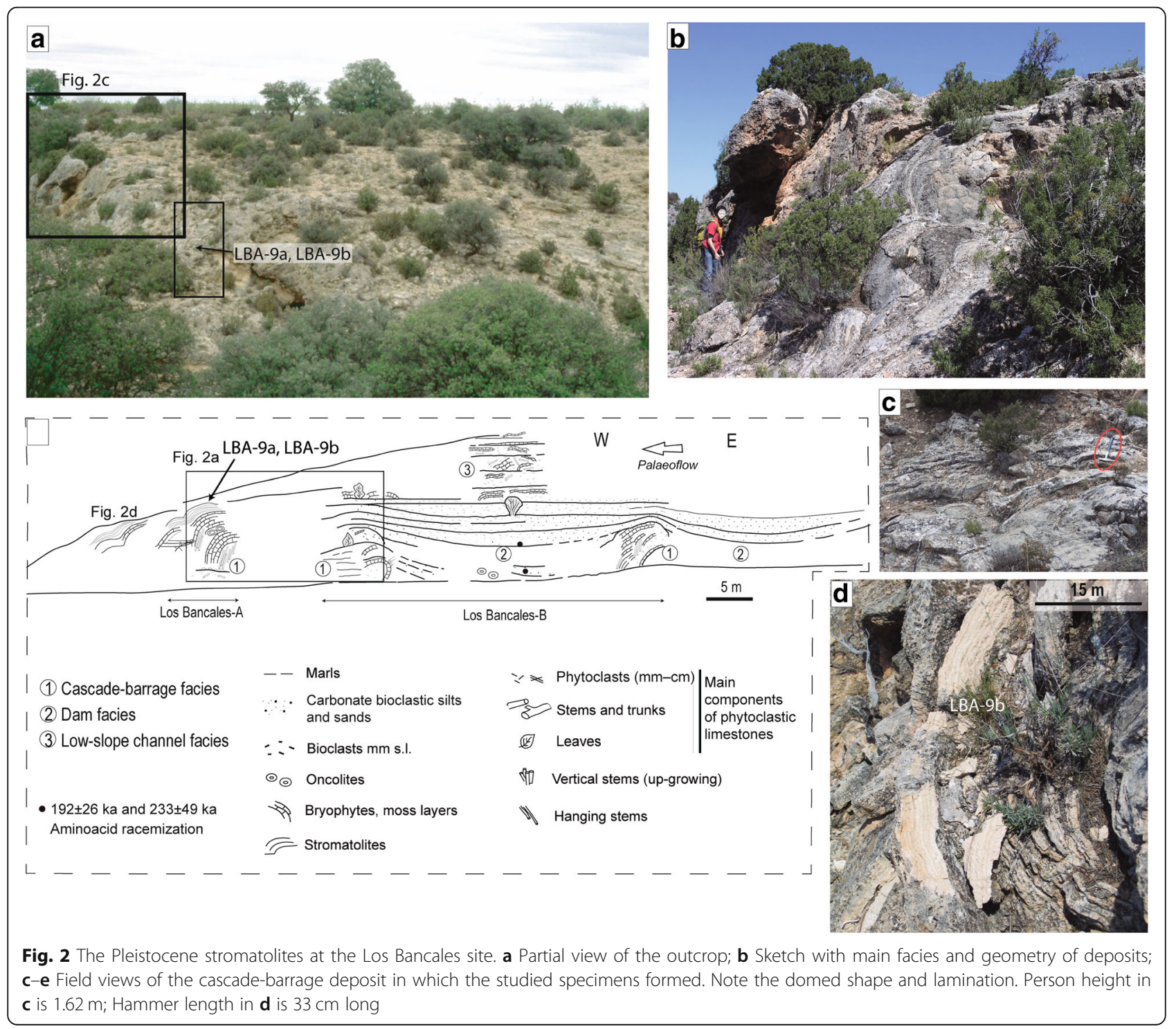


correlated to such pool facies deposits. Despite the uncertainty of dates, that time span is centered in the Marine Isotope Stage (MIS) 7 (Lisiecki and Raymo 2005), i.e. the middle Pleistocene.

\section{Materials and methods}

Texture and stable isotopes of two middle Pleistocene stromatolite specimens (LBA-9a and LBA-9b; Fig. 2) are studied and compared to one section of recent tufa (P-14) from a similar sedimentological and hydrological context.

\subsection{The recent stromatolite}

The recent stromatolite corresponds to the calcite deposit formed on an artificial substrate (limestone tablet $25 \times 16 \times 2 \mathrm{~cm}$ ) installed during the monitoring process of the River Piedra on a stepped cascade, ca. $3 \mathrm{~m}$ high, with fast flowing water (Fig. 3). The site P-14 was selected because of the continuous stromatolite records and high deposition rates, with patterns comparable to other monitored sites in the river (Arenas et al. 2014). There, tablet P-14 was first installed in autumn 2000 and then removed at the end of every summer and the end of every winter, in order to measure the thickness of the deposit during each six-month period (see procedure details in Vázquez-Urbez et al. 2010). These measures served later to identify the periods. Hereafter, the autumn-winter period is named the cool period, and spring-summer period the warm period. The tablet was substituted by a new one when the tufa thickness was too high for the measurement device, and definitively removed at the end of the summer of 2012. Therefore, the P-14 tablet deposit spans 12 years. The average water depth and velocity at the tablet site are $7.4 \mathrm{~cm}$ and $227.7 \mathrm{~cm} \cdot \mathrm{s}^{-1}$ in cool periods, and $6.5 \mathrm{~cm}$ and $221.5 \mathrm{~cm} \cdot \mathrm{s}^{-1}$ in warm periods (Arenas et al. 2014). In addition, water temperature $(T w)$ was measured by means of data loggers from October 2007 to September 2012 (Osácar et al. 2016).

The consecutive depositional records obtained at site P-14 were cut perpendicular to flow direction, and the corresponding sections were sampled with a microdrill of $0.4-0.8 \mathrm{~mm}$ diameter (Navfram model N120 Micromotor 25,000 rpm) for the stable isotope analyses. The results are reported in Osácar et al. (2016).

\subsection{The Pleistocene stromatolites}

Two representative stromatolite specimens (LBA-9a and LBA-9b) were collected close to each other on the steep surface of the downstream cascade-barrage deposit (Fig. 2). These samples are representative of the stromatolites in this stream and were selected for detailed study. Both specimens essentially consist of pure calcite, based on XRD analyses. Specimen LBA-9a is $13.7 \mathrm{~cm}$ thick and specimen LBA-9b is 8 $\mathrm{cm}$ thick (Figs. 4 and 5).

Powdered samples $(1 \mathrm{mg})$ were obtained, on polished slabs, from each consecutive light and dark laminae, that is, a total of 17 light and 16 dark laminae in specimen LBA-9a, and 12 light and 12 dark laminae in specimen LBA-9b. $\delta^{13} \mathrm{C}$ and $\delta^{18} \mathrm{O}$ analyses were done at the Serveis Cientifico-Tècnics of the University of Barcelona (Spain), using a Thermo Finnigan MAT-252 mass

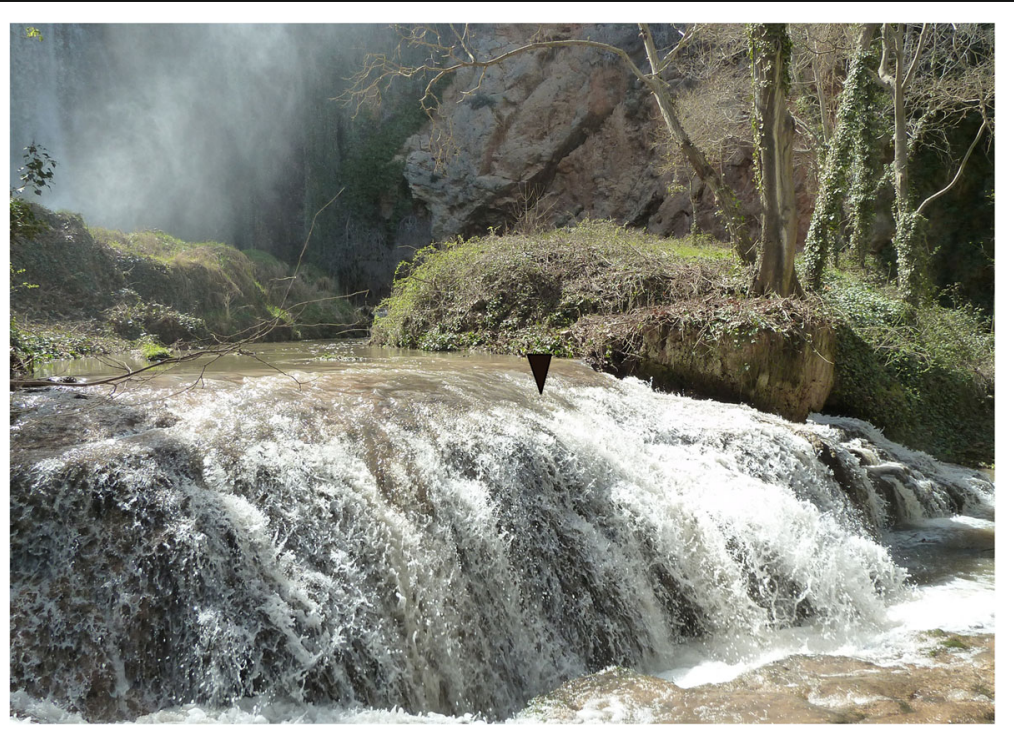

Fig. 3 Field image of the present cascade in the Monasterio de Piedra Natural Park, where stromatolites formed. The sedimentary records on tablets installed in that site (P-14) from 2000 to 2012 were used for comparison with the Pleistocene stromatolites. Black arrow points to the locus where tablets were installed 

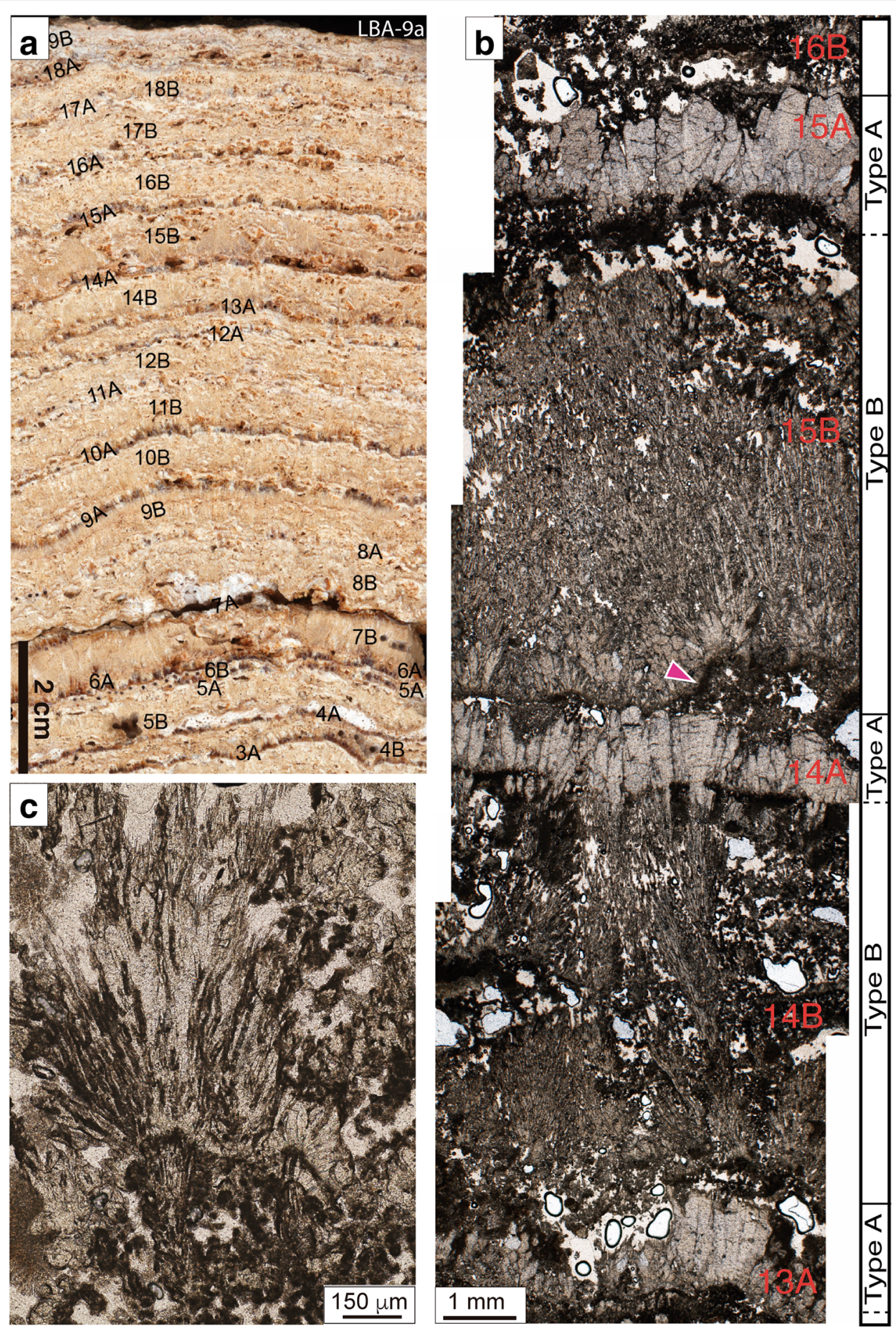

Fig. 4 Pleistocene stromatolite (specimen LBA-9a). a Polished section of a portion of the specimen, with laminae identification beside the sampled points ( $A$ and $B$ refer to the types of laminae described in the text); $\mathbf{b}$ Composite photomicrograph in optical microscope showing the two types of laminae. Note: in type B laminae the presence of bush-shaped filament arrangement, and the gradual passage from 14B to 14A, and the sharp contact at the top of the type A laminae. At the base of 15B, an erosional surface is arrowed; c Detail of a bush-shaped body consisting of calcite filamentous bodies, likely from cyanobacteria 

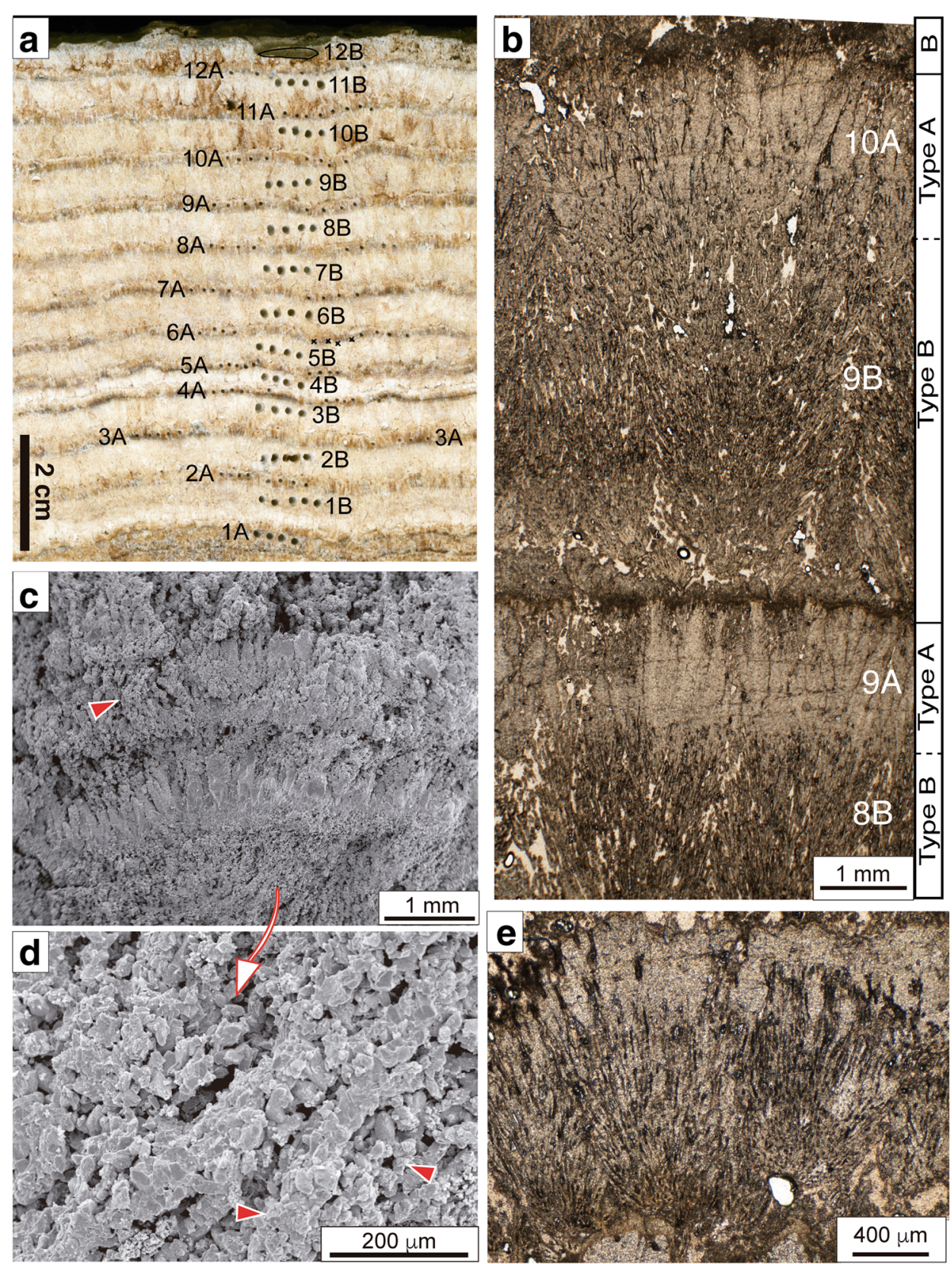

Fig. 5 Pleistocene stromatolite (specimen LBA-9b). a Polished section of a portion of the specimen, with laminae identification beside the sampled points ( $A$ and $B$ refer to the types of laminae described in the text); $\mathbf{b}$ and $\mathbf{e}$ Photomicrograph in optical microscope; $\mathbf{b}$ The two types of laminae. Note the gradual passage from type B to A and the sharp ending of type $\mathrm{A}$, which at places is highlighted by a thin micrite lamina; $\mathbf{c}$ and $\mathbf{d}$ Photomicrographs from scanning electron microscopy; $\mathbf{c}$ Detail of lamination. Note calcite tubes between the large-crystal laminae (red arrow); $\mathbf{d}$ Detail of calcite tubes in the type B laminae; e Detail of coalescent bush-shaped bodies consisting of calcite filamentous bodies, likely from cyanobacteria, in a type B lamina

spectrometer following standard procedures (Craig 1965). The isotopic results are expressed in $\delta \%$ Vienna Pee Dee Belemnite (VPDB) with an error margin of $0.04 \%$ for the $\delta^{13} \mathrm{C}$ and $0.12 \%$ for the $\delta^{18} \mathrm{O}$. The data were calibrated with international reference scales VPDB using International Atomic Energy Agency Certified
Reference Material NBS-19. Results are expressed in Table 1.

Mineralogy was determined by X-ray diffraction (XRD) using a Phillips PW 1729 diffractometer at the Servicios de Apoyo a la Investigación (SAI) of the University of Zaragoza. Several thin sections were made for 
Table $1 \delta^{18} \mathrm{O}$ and $\delta^{13} \mathrm{C}$ values of the two Pleistocene stromatolite specimens LBA-9a and LBA-9b) and the recent stromatolite (P-14)

\begin{tabular}{|c|c|c|c|c|c|}
\hline & \\
\hline Sample & $\delta^{18} \mathrm{O} \% \mathrm{VPDB}$ & $\delta^{13} \mathrm{C} \%$ VVPB & Sample & $\delta^{18} \mathrm{O} \% \mathrm{VPDB}$ & $\delta^{13} \mathrm{C} \% \mathrm{oVPDB}$ \\
\hline Section LBA-9a & & & LBA-9b 6B & -9.64 & -7.28 \\
\hline LBA-9a 1B & -9.20 & -6.76 & LBA-9b 7A & -8.12 & -7.86 \\
\hline LBA-9a 1A & -7.90 & -7.84 & LBA-9b 7B & -9.60 & -7.25 \\
\hline LBA-9a 2B & -9.57 & -7.29 & LBA-9b 8A & -7.44 & -7.20 \\
\hline LBA-9a 2A & -7.22 & -7.05 & LBA-9b 8B & -9.74 & -7.09 \\
\hline LBA-9a 3B & -9.22 & -6.95 & LBA-9b 9A & -7.74 & -7.50 \\
\hline LBA-9a 3A & -6.94 & -6.85 & LBA-9b 9B & -9.67 & -7.33 \\
\hline LBA-9a 4B & -8.54 & -6.59 & LBA-9b 10A & -7.45 & -7.30 \\
\hline LBA-9a 4A & -7.64 & -7.20 & LBA-9b 10B & -8.96 & -7.32 \\
\hline LBA-9a 5B & -9.21 & -7.25 & LBA-9b 11A & -7.37 & -7.14 \\
\hline LBA-9a 5 A & -7.22 & -6.78 & LBA-9b 11B & -8.47 & -7.08 \\
\hline LBA-9a 7B & -9.41 & -7.80 & LBA-9b 12A & -7.12 & -7.16 \\
\hline LBA-9a 7A & -6.85 & -7.72 & LBA-9b 12B & -8.17 & -6.38 \\
\hline LBA-9a 8B & -8.91 & -7.12 & Section P-14 & & \\
\hline LBA-9a 8A & -7.53 & -7.12 & Cool 00-01 & -7.92 & -8.16 \\
\hline LBA-9a 9B & -8.58 & -7.46 & Warm 2001 & -8.81 & -8.01 \\
\hline LBA-9a 9A & -6.94 & -7.47 & Cool 01-02 & -7.22 & -7.03 \\
\hline LBA-9a 10B & -8.96 & -7.11 & Warm 2002 & -8.02 & -7.24 \\
\hline LBA-9a 10A & -7.00 & -6.93 & Cool 02-03 & -8.44 & -8.30 \\
\hline LBA-9a 11B & -9.41 & -7.16 & Warm 2003 & & \\
\hline LBA-9a 11A & -7.51 & -6.95 & Cool 03-04 & & \\
\hline LBA-9a 12B & -9.24 & -6.94 & Warm 2004 & -8.47 & -8.52 \\
\hline LBA-9a 12A & -7.00 & -6.51 & Cool 04-05 & -7.12 & -8.03 \\
\hline LBA-9a 14B & -9.09 & -7.03 & Warm 2005 & -8.58 & -8.29 \\
\hline LBA-9a 14A & -7.59 & -7.74 & Cool 05-06 & -7.34 & -8.09 \\
\hline LBA-9a 15B & -9.23 & -7.54 & Warm 2006 & -9.01 & -8.34 \\
\hline LBA-9a 15A & -6.96 & -7.28 & Cool 06-07 & -7.64 & -8.17 \\
\hline LBA-9a 16B & -8.94 & -7.07 & Warm 2007 & -8.59 & -8.28 \\
\hline LBA-9a 16A & -6.92 & -7.36 & Cool 07-08 & -7.52 & -8.20 \\
\hline LBA-9a 17B & -8.89 & -6.91 & Warm 2008 & -8.47 & -8.22 \\
\hline LBA-9a 17A & -7.30 & -6.24 & Cool 08-09 & -7.56 & -7.94 \\
\hline LBA-9a 18B & -8.14 & -5.99 & Warm 2009 & -8.62 & -8.33 \\
\hline LBA-9a 18A & -7.45 & -7.00 & Cool 09-10 & -8.12 & -7.67 \\
\hline LBA-9a 19B & -8.02 & -6.32 & Warm 2010 & -9.07 & -7.70 \\
\hline Section LBA-9b & & & Cool 10-11 & -8.44 & -7.59 \\
\hline LBA-9b $1 \mathrm{~A}$ & -7.51 & -7.47 & Warm 2011 & -8.86 & -7.56 \\
\hline LBA-9b 1B & -9.53 & -7.29 & Cool 11-12 & -7.93 & -7.09 \\
\hline LBA-9b 2A & -7.83 & -7.39 & Warm 2012 & -8.69 & -7.46 \\
\hline LBA-9b $2 B$ & -8.85 & -7.59 & & & \\
\hline LBA-9b 3A & -7.20 & -7.11 & & & \\
\hline LBA-9b 3B & -9.02 & -7.13 & & & \\
\hline LBA-9b 4A & -7.25 & -6.87 & & & \\
\hline LBA-9b 4B & -8.74 & -6.81 & & & \\
\hline LBA-9b 5A & -8.54 & -7.39 & & & \\
\hline LBA-9b 5B & -9.43 & -7.04 & & & \\
\hline LBA-9b 6A & -8.34 & -7.52 & & & \\
\hline
\end{tabular}

Table $1 \delta^{18} \mathrm{O}$ and $\delta^{13} \mathrm{C}$ values of the two Pleistocene stromatolite specimens LBA-9a and LBA-9b) and the recent stromatolite (P-14) (Continued) 
textural and structural analyses through petrographic microscopy, and small solid pieces $\left(2 \times 5 \times 8 \mathrm{~mm}^{3}\right)$ were used for scan electron microscopy (SEM) (Carl Zeiss MERLIN $^{\mathrm{sm}}$ FESEM), operating at 3-15 kV and $158 \mathrm{pA}$ ), at the SAI of the University of Zaragoza.

\subsection{Temperature calculation}

In both Pleistocene and recent stromatolites, temperature from calcite $\delta^{18} \mathrm{O}$ was estimated by means of the equations of O'Brien et al. (2006) and Kim and O'Neil (1997), the latter corrected for acid reaction fractionation (Böhm et al. 2000; Affek et al. 2008). Mean water $\delta^{18} \mathrm{O}$ used in these equations was obtained by measurement in up to 12 sites through a 13-year monitoring: $\delta^{18} \mathrm{O}=-8.5 \%$ SMOW (standard mean ocean water) for warm periods and $\delta^{18} \mathrm{O}=-8.6 \%$ SMOW for cool periods (Osácar et al. 2016).

\section{Results}

\subsection{The recent stromatolite}

The textural and isotopic data of the recent stromatolite used here (record on tablet P-14) have been already published (Osácar et al. 2016; Arenas and Jones 2017; Arenas et al. 2018), but a summary is included in this section as contextual information for the comparison with the Pleistocene stromatolites.

\subsubsection{Structure and texture}

The stromatolites developed on tablet P-14, made entirely of calcite, consist of alternating dense and porous composite laminae, with less common macrocrystalline laminae (Fig. 6). The dense and porous composite laminae (up to $15 \mathrm{~mm}$ and $12 \mathrm{~mm}$ thick, respectively) are formed of several dense and porous single laminae (Fig. 6; see also Arenas and Jones 2017). These laminae are composed of tubes formed by calcite precipitation around filamentous cyanobacteria, primarily Phormidium incrustatum (Berrendero et al. 2016). The porous laminae are dominant in the cool period deposits, and the dense laminae are dominant in the warm period deposits. Each composite lamina, either dense or porous, represents a few months (typically up to about six months) of deposition (Arenas and Jones 2017). The macrocrystalline laminae (up to 1.7 $\mathrm{mm}$ thick) are formed of elongate crystals (up to 1 $\mathrm{mm}$ long). These laminae are conspicuous at the base of most cool period deposits, but are also present in warm period deposits (Fig. 6).

\subsubsection{Stable isotopes and temperature estimation}

The $\delta^{18} \mathrm{O}$ values of this stromatolite range from $-7.12 \%$ to $-9.07 \%$ VPDB. Mean $\delta^{18} \mathrm{O}$ of warm periods is significantly lower $\left(-8.65 \%\right.$ VPDB) than mean $\delta^{18} \mathrm{O}$ of cool periods $(-7.75 \%$ VPDB) (Table 2; source data of each analyzed point are plotted in Fig. 7). The time evolution also exhibits the cyclic pattern expected from the temperature-dependent fractionation of oxygen, that is, the $\delta^{18} \mathrm{O}$ values of warm periods are lower than the $\delta^{18} \mathrm{O}$ values of cool periods (Fig. 7c). Altogether, $\delta^{18} \mathrm{O}_{\text {cal- }}$ cite show a trend towards lower values through time.

The difference between the $T w$ means of cool and warm periods, measured between 2007 and 2012, is 5.71 ${ }^{\circ} \mathrm{C}$ (minimum $=10.48{ }^{\circ} \mathrm{C}$, maximum $=16.19^{\circ} \mathrm{C}$; Arenas et al. 2014; Osácar et al. 2016). For the same time span, the difference between the $\delta^{18} \mathrm{O}$ means of cool and warm periods in stromatolites at site P-14 is $1.55 \%$ ( maximum $=-7.52 \%$, minimum $=-9.07 \%$ ).

The estimation of $T w$ (using the mean water $\delta^{18} \mathrm{O}$ measures, as explained in Methods; section 3.3) yielded temperatures close to the $T w$ measured during the monitoring survey (Table 3 ). These calculated $T w$ values are also close to the coetaneous local air temperatures (Tair). Maximum and minimum mean six-month Tair are $11.3^{\circ} \mathrm{C}$ and $16.9^{\circ} \mathrm{C}$. These results point to the calcite being precipitated close to isotopic equilibrium (Osácar et al. 2016).

The $\delta^{13} \mathrm{C}$ values of $\mathrm{P}-14$ range from $-7.03 \%$ to $-8.52 \%$ VPDB (Table 1). There is no relevant difference between mean $\delta^{13} \mathrm{C}$ values of warm $(-8.00 \%$ VPDB) and cool periods $\left(-7.84 \%\right.$ VPDB) and the $\delta^{13} \mathrm{C}$ time evolution does not show any pattern (Fig. 7c). Values of $\delta^{13} \mathrm{C}$ in tufa calcite presently precipitating in the River Piedra are higher than the corresponding $\delta^{13}$ dissolved inorganic carbon $\left(\delta^{13} C_{\text {DIC }}\right)$ values. Differences are in the expected range from the equilibrium isotopic fractionation, suggesting that carbon isotopic fractionation in these modern tufas is at or near isotopic equilibrium (Osácar et al. 2013, 2016). The two-period moving mean, calculated to remove the cyclic pattern, shows the evolution of both $\delta^{13} \mathrm{C}$ and $\delta^{18} \mathrm{O}$ through time. They exhibit an evident parallelism until Cool $09-10$ period (Fig. 7c), when $\delta^{18} \mathrm{O}$ starts a distinct decreasing trend that is correlated to the simultaneous decrease of the river discharge (Osácar et al. 2016).

\subsection{The middle Pleistocene stromatolites 4.2.1 Structure and texture}

The studied stromatolites have a multi-convex morphology, with decimeter- to meter-wide domes, developed through surfaces that are (sub) vertical at the top to (sub)horizontal at the distal part of the cascade-barrage deposit. In all cases, the laminae mimic the macroscale shapes. In hand specimen, lamination consists of alternating dark and light calcite laminae (Figs. 4a and 5a), which under the optical microscope correspond, respectively, to (i) light, large-crystal laminae, and (ii) dark, small-crystal laminae (Figs. 4b and 5b). The laminae are smooth and rarely show gentle undulations. Both types 

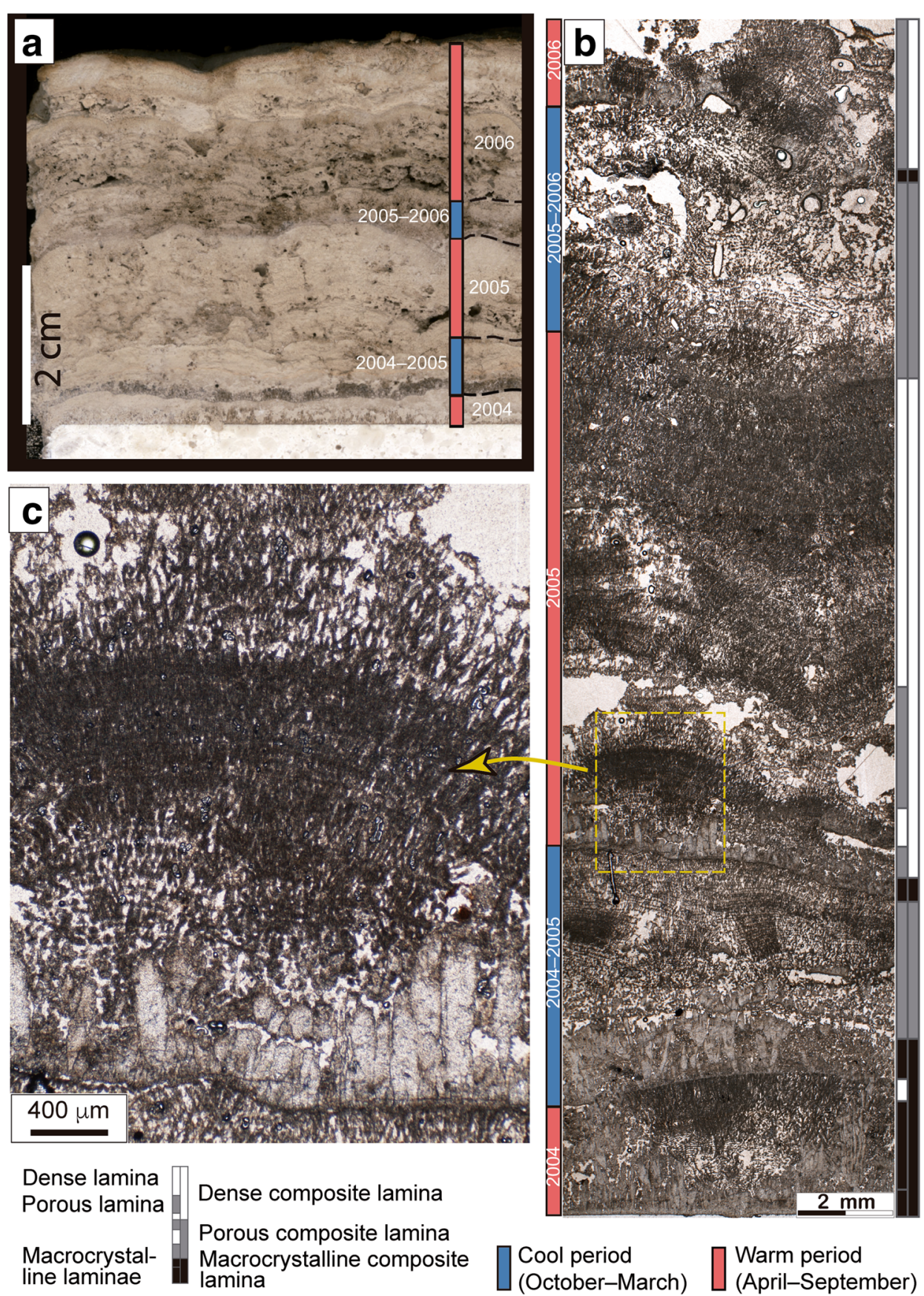

Fig. 6 Recent stromatolite formed at site P-14 (see Fig. 2). a Portion of a cross-section of deposit on a tablet, with the identification of six-month deposits. Note the dominant lamination and dense fabric in the warm-period deposits. A macrocrystalline lamina is distinguished at the base of the cool period (2004-2005) deposits; b Photomicrograph of a portion of A with indication of six-month periods and the three types of laminae; c Detail of a portion of $\mathbf{b}$, showing a macrocrystalline lamina over a sharp base and then overlain by micrite cyanobacterial filaments arranged as a fan-shaped body

of laminae are single and, in a few cases, composite laminae, which are composed of thinner laminae that differ from one another in crystal size (Figs. 4 and 5).

The light (under microscope), large-crystal laminae (hereafter type A laminae) are $0.5-2.2 \mathrm{~mm}$ thick, being most common the laminae $1-1.2 \mathrm{~mm}$ thick in the two studied specimens. Type A laminae exhibit columnar crystals that commonly widen upwards, up to $0.3 \mathrm{~mm}$ wide and $1 \mathrm{~mm}$ long. The crystals are grouped laterally, in some cases as adjacent fan-shaped bodies, forming palisades that at places can show gently domed tops. Most commonly, these 
Table 2 Statistical data of stable isotopes of the Pleistocene and recent stromatolites

\begin{tabular}{|c|c|c|c|c|c|c|}
\hline$\delta^{18} \mathrm{O}$ (\%o VPDB) & Mean & Difference between means & Maximum & Minimum & Lamina range & Total range \\
\hline LBA-9a B & -8.97 & -1.68 & -8.02 & -9.57 & 1.55 & -2.72 \\
\hline LBA-9a A & -7.29 & & -6.85 & -8.07 & 1.22 & \\
\hline LBA-9b B & -9.15 & -1.49 & -8.17 & -9.74 & 1.57 & -2.62 \\
\hline LBA-9b A & -7.66 & & -7.12 & -8.54 & 1.42 & \\
\hline P-14 warm & -8.65 & -0.90 & -8.02 & -9.07 & 1.05 & -1.95 \\
\hline P-14 cool & -7.75 & & -7.12 & -8.44 & 1.32 & \\
\hline$\delta^{13} \mathrm{C}(\% \circ \mathrm{VPDB})$ & Mean & Difference between means & Maximum & Minimum & Lamina range & Total range \\
\hline LBA-9a B & -7.02 & 0.12 & -5.99 & -7.80 & 1.81 & 1.91 \\
\hline LBA-9a A & -7.14 & & -6.24 & -7.90 & 1.66 & \\
\hline LBA-9b B & -7.13 & 0.20 & -6.38 & -7.59 & 1.21 & 1.48 \\
\hline LBA-9b A & -7.33 & & -6.87 & -7.86 & 0.99 & \\
\hline P-14 warm & -8.00 & -0.16 & -7.24 & -8.52 & 1.28 & 1.49 \\
\hline P-14 cool & -7.84 & & -7.03 & -8.30 & 1.27 & \\
\hline
\end{tabular}

laminae are the upward transition from the type B laminae. The tops of the large crystals can show sharp endings. In some cases, the large crystals show overgrowing larger crystals. Within some crystals, elongated bodies that are attributed to filamentous microbes can be seen parallel to the crystal length. Some cyanobacterial tubes can be filled by calcite, in particular at the contact with the type B laminae. Porosity in type A laminae is very low, mostly intercrystalline $(<5 \%$ from visual estimations in the microscope).

The dark (under microscope), small-crystal laminae (hereafter type B laminae) are 1.9-6 mm thick. Most common thickness is $5 \mathrm{~mm}$ in specimen LBA-9a and 3 $\mathrm{mm}$ in specimen LBA-9b, respectively. These laminae are micritic to sparitic, though large columnar crystals may also be present, in particular in the upper part of the laminae, through the passage to the type A laminae. Micrite and microsparite appear forming filamentous bodies grouped into adjacent bunches and fan-shaped bodies, up to $1.5 \mathrm{~mm}$ high, which are attributed to filamentous cyanobacteria (Figs. 4c, 5b and e). The individual filamentous bodies are preserved as calcite tubes (inner diameter 5-7 $\mu \mathrm{m}$ wide and coating approximately $7-10 \mu \mathrm{m}$ thick). Matrix among the filaments is composed of clotted micrite and microsparite (euhedral and subhedral calcite). Porosity is of growth-framework, mouldic (from insects) and intergranular types (approximately $10 \%-15 \%$ from visual estimates in the microscope).

Commonly, upward transitions from the type B laminae to type A laminae are gradational (Figs. 4b and $5 \mathrm{~b})$. Conversely, the passage from type A laminae to type B laminae is mostly sharp, in some cases coinciding with a thin layer $(<40 \mu \mathrm{m})$ of much smaller calcite crystals (Fig. 5b). The boundaries from type A laminae to type B laminae can also be gradational. In this case, there is commonly an increase in crystal size upwards. Dissolution features are rare, but can be observed at the top of some type A laminae (e.g. top of lamina 14A in specimen LBA-9a, Fig. 4b). Erosional features are rare and occur at the top of the type B laminae (e.g., at the boundary between 14A and $15 \mathrm{~B}$ in specimen LBA-9a (Fig. 4b).

\subsubsection{Stable isotopes and temperature estimation}

The $\delta^{18} \mathrm{O}$ and $\delta^{13} \mathrm{C}$ values of the laminae in the Pleistocene specimens range from $-6.85 \%$ to $-9.74 \%$ PDB and $-5.99 \%$ to $-7.90 \%$ VPDB, respectively (Table 2 ). $\delta^{18} \mathrm{O}$ and $\delta^{13} \mathrm{C}$ are of the same order in both studied specimens, although the mean values of specimen LBA-9b are slightly lower (Table 2). The difference between the mean $\delta^{18} \mathrm{O}$ of the two lamina types is $1.68 \%$ PDB for specimen LBA-9a and 1.49\% VPDB for LBA-9b. The mean $\delta^{13} \mathrm{C}$ difference, significantly lower, is $0.12 \%$ VPDB for specimen LBA-9a and $0.20 \%$ VPDB for LBA-9b.

In both specimens, $\delta^{18} \mathrm{O}$ values show an evident rhythmic pattern through time, with higher values in the type A laminae than in the type B laminae (Fig. $7 \mathrm{a}$ and b). Mean $\delta^{18} \mathrm{O}$ are $-7.29 \%$ and $-7.66 \%$ VPDB in lamina A for specimens LBA-9a and LBA-9b respectively, and $-8.97 \%$ and $-9.15 \%$ VPDB in lamina B for specimens LBA-9a and LBA-9b respectively (Table 2). Given the dominant influence of temperature on ${ }^{18} \mathrm{O} /{ }^{16} \mathrm{O}$ fractionation in fluvial environments (e.g., Leng and Marshall 2004), the rhythmic $\delta^{18} \mathrm{O}$ pattern represents the oscillation between low- and high-temperature deposits. The time span of each type of lamina is unknown and they do not necessarily represent equal durations. Therefore, 

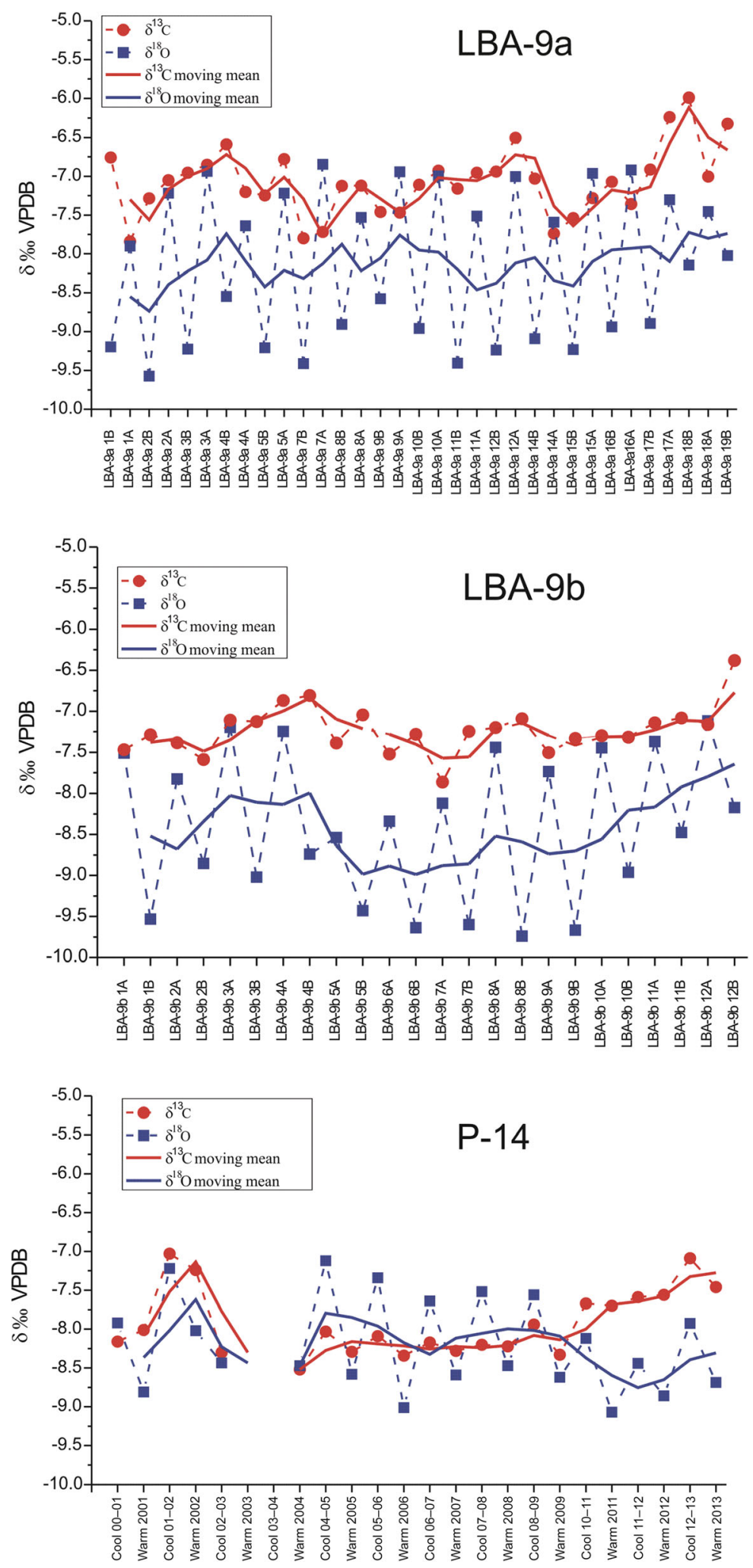

Fig. 7 Evolution of $\delta^{18} \mathrm{O}$ and $\delta^{13} \mathrm{C}$ of the Pleistocene (a and $\mathbf{b}$ ) and recent stromatolites (c) through time. Continuous lines correspond to the two-period moving means 
Table 3 Mean calculated water temperatures of stromatolite calcite precipitation

\begin{tabular}{lll}
\hline & $\begin{array}{l}\operatorname{Tw}\left({ }^{\circ} \mathrm{C}\right) \\
\text { Kim and O'Neil (1997) eq. }\end{array}$ & $\begin{array}{l}\text { Tw }\left({ }^{\circ} \mathrm{C}\right) \\
\text { O'Brien et al. (2006) eq. }\end{array}$ \\
\hline LBA-9a B & 17.0 & 17.5 \\
LBA-9a A & 8.9 & 9.9 \\
LBA-9b B & 17.9 & 18.3 \\
LBA-9b A & 10.5 & 11.3 \\
P-14 warm & 15.5 & 16.0 \\
P-14 cool & 11.3 & 12.0 \\
\hline
\end{tabular}

hereafter, type A laminae correspond broadly to the cool period deposits, and type B laminae to the warm period deposits. Assuming that these changes are biannual, each couple $(\mathrm{A}+\mathrm{B})$ represents one year (e.g., Arenas et al. 2018). Therefore, the analyzed specimens represent 16.5 years (LBA-9a) and 12 years (LBA-9b), respectively. Hence, although cool- and warm-period laminae of the recent stromatolite are not fully equivalent to the type $\mathrm{A}$ and type B laminae of the Pleistocene specimens, they are comparable, taken into account the possible duration difference.

The $\delta^{13} \mathrm{C}$ values do not show a distinct pattern through the analyzed specimens (Fig. 7), although the mean $\delta^{13} \mathrm{C}$ in type A laminae is lower than mean $\delta^{13} \mathrm{C}$ in type $\mathrm{B}$ laminae, in both specimens (Table 2). The two-period moving mean time of $\delta^{18} \mathrm{O}$ and $\delta^{13} \mathrm{C}$ shows parallel time evolution in both specimens (Fig. 7).

The estimation of the water temperatures from $\delta^{18} \mathrm{O}_{\text {calcite }}$ of fossil carbonates requires selecting a water $\delta^{18} \mathrm{O}$ value, which is not possible to know directly. In this study case, the present $\delta^{18} \mathrm{O}$ values of the River Piedra water measured in cool and warm periods (Osácar et al. 2016) are used. The mean estimated temperatures for the type $\mathrm{A}$ laminae and type $\mathrm{B}$ laminae range from $8.9^{\circ} \mathrm{C}$ to $18.3^{\circ} \mathrm{C}$ (Table 3).

\section{Discussion: Comparison of Pleistocene and recent stromatolite records}

\subsection{Structure and texture}

The recent fluvial stromatolites show thickness, texture and porosity variations of the laminae that are comparable to the Pleistocene examples. The alternating thin large-crystal laminae (type A laminae) and thick small-crystal laminae (type B laminae) in the Pleistocene stromatolites can be compared with the recent lamination as the textural rhythmicity reflects the different growth of the microbial mats, being much smaller or even absent during the type A lamina formation. Despite not being totally time-equivalent, the macrocrystalline laminae in the recent stromatolite resemble the large-crystal laminae (type A laminae) in the ancient examples (compare Figs. 4, 5 and 6). In fact, the best development of the macrocrystalline laminae occur within the six-month cool period deposits, which is consistent with the formation of the type A laminae during the cool seasons in the Pleistocene samples.

In the Pleistocene stromatolites, the gradual transition from type B laminae to type A laminae suggests decreased development of the surface activity of the microbial mat (mainly cyanobacteria) as temperature and light decrease, i.e., at the end of the autumn and in winter. The limited bacterial growth during the coldest moments causes that calcite precipitation, whenever the chemical conditions are suitable, can occur outside the biofilm (i.e., extra-EPS, extracellular polymeric substances, sites of Pedley 2014), favoring abiogenic precipitation of large calcite crystals (Pedley 2014). This type of calcification may occur during autumn and winter, favoring large-crystal calcite growth on and into the cyanobacterial mat (cf. Pentecost 1987, 1988). In the studied recent fluvial stromatolites, sharp bases below macrocrystalline laminae suggest breaks in the cyanobacterial growth at discrete times (Arenas and Jones 2017). Either erosion or seasonally low temperatures can cause these interruptions (cf. Arp et al. 2010). The sharp textural passages from type A laminae to type B laminae rather suggest breaks in calcite precipitation.

These results support that the formation of the small-crystal laminae are linked to calcite precipitation associated to the microbial activity (i.e., intra-EPS sites of Pedley 2014), which is favored in the warm seasons. In contrast, large-crystal laminae reflect calcite precipitation in the absence of microbial mats, which can occur in cold conditions, or after erosional episodes, or even on blank substrates.

\subsection{Stable isotope composition 5.2.1 Oxygen isotopes}

The $\delta^{18} \mathrm{O}$ values of Pleistocene and recent stromatolites are quite similar (Fig. 7 and Table 3); the calculated $T w$ values are also close to the present measured $T w$ values in the River Piedra. This agreement points to Pleistocene calcite being precipitated close to isotopic equilibrium, i.e., the conditions represented by the equations of O'Brien et al. 2006 and Kim and O'Neil 1997. This condition (near-isotopic equilibrium tufa formation) has been also claimed for other fossil tufa, either Pleistocene (Anzalone et al. 2007; Brasier et al. 2010), Holocene (Garnett et al. 2004; O’Brien et al. 2006) or even Eocene (Chafetz et al. 1991), as well as for the recent tufa in the River Piedra (Osácar et al. 2013, 2016).

Nevertheless, some significant differences arise when the data dispersion is considered. The $\delta^{18} \mathrm{O}$ of both Pleistocene specimens display wider variability than the recent stromatolite (P-14). The total $\delta^{18} \mathrm{O}$ ranges, as well as the differences between the $\delta^{18} \mathrm{O}$ mean values, are 
larger in the Pleistocene specimens than in the recent stromatolite. Total ranges are, LBA-9a: $-2.72 \%$ VPDB, LBA-9b: $-2.62 \%$ VPDB, and P-14: $-1.95 \%$ VPDB, respectively. Differences between lamina mean values are, LBA-9a: $-1.68 \%$ VPDB, LBA-9b: $-1.49 \%$ VPDB, and P-14: $-0.90 \%$ VPDB, respectively (Table 2). In the case of type B laminae, the relatively larger variability could be attributed to their longer duration, more than six months, however, the range of type A laminae is not shrunk in the same proportion. These circumstances confirm the larger isotopic variability of Pleistocene stromatolites and suggests that type B laminae represent longer duration than the recent warm period laminae, whereas type A laminae duration should be shorter than the recent cool-period laminae; this is consistent with the fact that the type A laminae of Pleistocene deposits are equivalent to the macrocrystalline laminae within the cool period deposits of the recent stromatolite.

The wide biannual rhythmic variation of $\delta^{18} \mathrm{O}$ gives evidence of temperature being the main control factor of the calcite oxygen isotopic composition. Other possible factors, such as water $\delta^{18} \mathrm{O}$ fluctuations can be discarded. Seasonal variations of the river water $\delta^{18} \mathrm{O}$ composition, according to the spring-water $\delta^{18} \mathrm{O}$ oscillations (higher values in spring-summer and lower in autumnwinter; Osácar et al. 2016), would have weakened the pulse amplitude caused by water temperature on the calcite $\delta^{18} \mathrm{O}$. Therefore, the wide calcite $\delta^{18} \mathrm{O}$ range suggests the stability of river water $\delta^{18} \mathrm{O}$ signature (Hori et al. 2009). This situation is compatible with most of the river water being supplied by the aquifer, with very minor water inputs from other sources (e.g. runoff). Moreover, in this situation, water would have been chemically homogenized within the aquifer, to some extent. As for evaporation, it should have little effect on water of hydrologically open systems, as is the studied case. Finally, the regularity of the calcite $\delta^{18} \mathrm{O}$ oscillations suggests that diagenesis has not altered the seasonal isotopic signature (cf. Brasier et al. 2011).

Therefore, according to the temperature dependence of the ${ }^{18} \mathrm{O} /{ }^{16} \mathrm{O}$ fractionation, the Pleistocene stromatolite $\delta^{18} \mathrm{O}$ oscillations reflect the corresponding water temperature oscillations, that would have been wider than presently. Using the present measured $\delta^{18} \mathrm{O}$ of water, a seasonal temperature variation of $7^{\circ} \mathrm{C}$ to $8.1^{\circ} \mathrm{C}$ for the Pleistocene $T w$ and $4{ }^{\circ} \mathrm{C}$ for the present $T w$ (Table 3) are estimated. Assuming the River Piedra behavior in the Pleistocene was similar to the present, relative to the seasonal oscillations of the average Tair mimicking the measured mean $T w$ variations, the Pleistocene stromatolites indicate a more contrasted seasonal temperature than presently. Attention should be paid to the fact that tufa rate deposition decreases at a low temperature, therefore, periods of lower temperatures may be not recorded by tufa (Mischke and Zhang 2008; Arenas et al. 2018).

The higher than present $T w$ inferred from the Pleistocene stromatolite are consistent with the deposit being formed during one of the interglacial substages of MIS 7 (Sancho et al. 2015). Tufa deposition during MIS 7 in the Iberian Ranges is regulated by biostatic environments sensitive to the precipitation regime and summer insolation, probably under warmer and wetter conditions than the present (Sancho et al. 2015) and it shows a high climate variability (Lisiecki and Raymo 2005). Thus, climate comparison between MIS 7 and the present becomes a complex subject. More robust chronological data from local fluvial tufa records and more precise Iberian regional palaeoclimatic reconstructions are undoubtedly necessary to address this goal.

\subsubsection{Carbon isotopes}

The mean $\delta^{13} \mathrm{C}$ values of the Pleistocene specimens are higher than those in the recent stromatolite, especially in sample LBA-9a, which shows the highest $\delta^{13} \mathrm{C}$ values (Table 2; Fig. 8). In the two Pleistocene specimens, the mean $\delta^{13} \mathrm{C}$ values are higher in the type $\mathrm{B}$ laminae (warm periods). In contrast, in the recent stromatolite, the mean $\delta^{13} \mathrm{C}$ values are lower in warm periods than in cool periods (Table 2). The total $\delta^{13} \mathrm{C}$ ranges in the Pleistocene stromatolites are similar (1.48\% in LBA-9b) or wider $(1.91 \%$ in LBA-9a) than in the recent stromatolite $(1.49 \%)$, and slightly wider in type B laminae than in type A laminae (Table 2 and Fig. 7).

Despite these differences, most of the $\delta^{13} \mathrm{C}$ values in the Pleistocene specimens (except those from the type $B$ laminae of LBA-9a) are included in the field of the present stromatolites recorded in the River Piedra from 1999 to 2012, both in the cool and warm periods (Fig. 8). As calcite $\delta^{13} \mathrm{C}$ in these environments usually reflects the water $\delta^{13} \mathrm{C}_{\mathrm{DIC}}$, it can be assumed that the $\delta^{13} C_{\text {DIC }}$ values of the Pleistocene waters should be also similar to the present water values, reflecting also a mixture of carbon derived from soil-derived organic matter, dissolution of carbonate bedrock in the aquifer, influence of photosynthesis and $\mathrm{CO}_{2}$ degassing along the river, as in the present River Piedra (cf. Usdowski et al. 1979; Andrews et al. 1993; Pentecost 2005; Andrews 2006). The only exception is the warm-period laminae of specimen LBA-9a, whose $\delta^{13} \mathrm{C}$ are shifted towards less negative values than the other modern and old samples compared in this study (Fig. 8), suggesting the influence of additional processes in the isotopic signature of this sample.

The difference between $\delta^{13} \mathrm{C}$ of the recent and the Pleistocene stromatolites is, in general, smaller than the $\sim 1.5 \%$ o VPDB difference due to the Suess Effect. The 


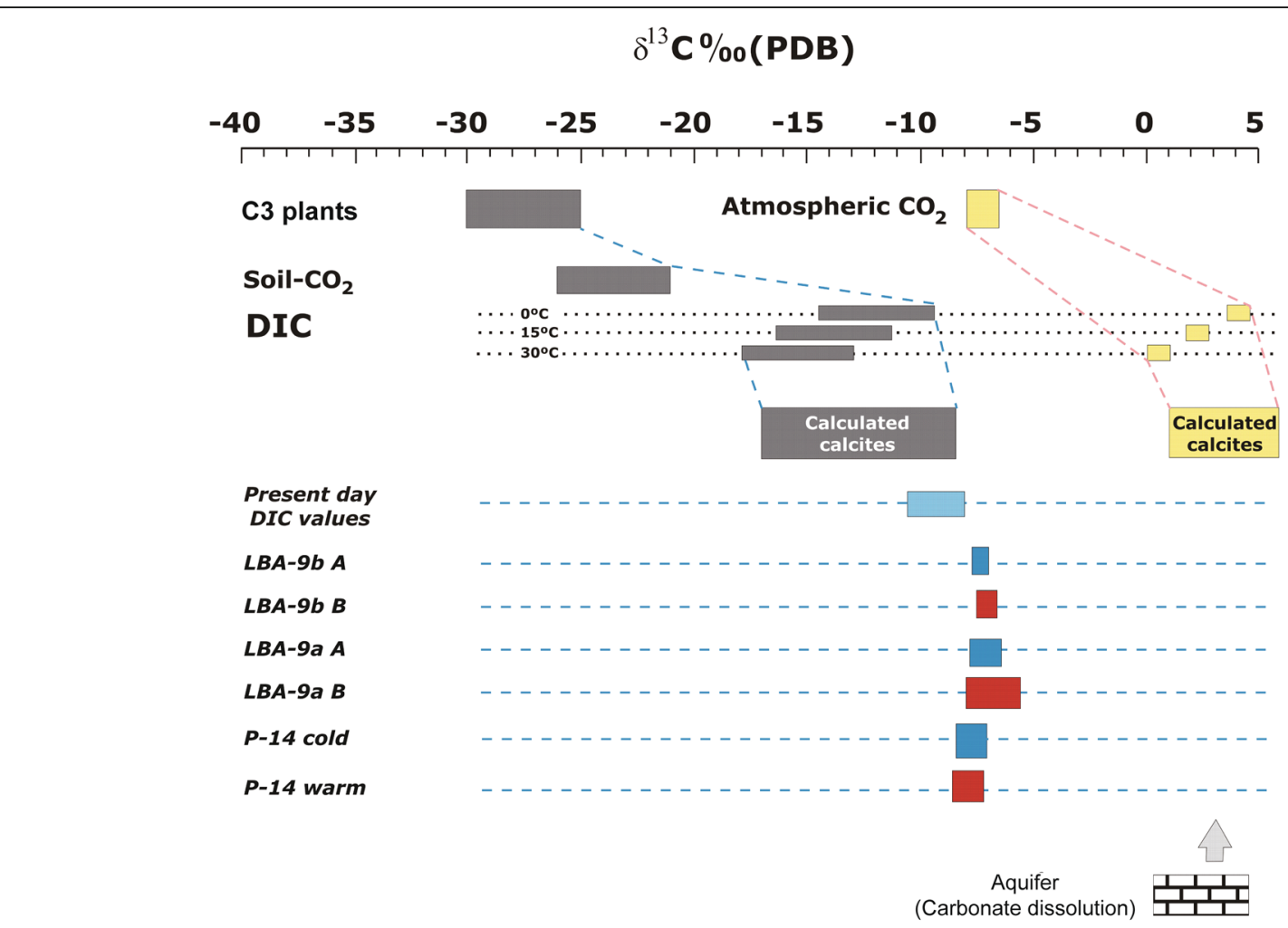

Fig. 8 Carbon isotopic values $\left({ }^{13} \mathrm{C}\right)$ for the Pleistocene tufas during cold and warm periods compared with those in the present-day dissolved inorganic carbon (DIC, from -8.1\%o to -10.5\%; Osácar et al. 2016), in the modern precipitates recorded in the River Piedra (data from P-14 record are separately shown) and all of them related with the most probable sources of carbon. Only C3-metabolism plants and atmospheric $\mathrm{CO}_{2}$ have been considered (C4- and crassulacean acid-metabolism plants are not present in the area). The C3 range (shaded in gray) is the most frequent range for C3 plants (Deines 1980; Cerling 1991; Killops and Killops 2005). The range for atmospheric $\mathrm{CO}_{2}$ is defined by the pre-industrial and the present atmospheric value $\left({ }^{13} \mathrm{C}=-6.5 \%\right.$ and $-8 \%$, respectively; Friedli et al. 1986). The soil- $\mathrm{CO}_{2}$ is about $4.5 \%$ o heavier than the plant biomass (Cerling 1984, 1991). The isotopic difference between soil- $\mathrm{CO}_{2}$ and $\mathrm{DIC}$ depends on the $\mathrm{pH}$ and temperature. At pH values close to 5 this difference is near 0\%; but at pH values between 7.5 and 8, it is relatively independent of pH (Romanek et al. 1992). The theoretical isotopic DIC and calcite values have been obtained considering a calcite-bicarbonate enrichment of $1 \%$ (independent of temperature) and the calcite- $\mathrm{CO}_{2}$ equation proposed by Romanek et al. (1992) for temperatures of $0,15^{\circ} \mathrm{C}$ and $30^{\circ} \mathrm{C}$. A $\delta^{13} \mathrm{C}$ value $(+3.2 \%$ ) for the carbonate aquifer (Upper Cretaceous limestones) feeding the Piedra River is available from IGME (1982). Modified from Ortiz et al. (2009)

relative depletion of ${ }^{13} \mathrm{C}$ in the atmosphere resulting from the addition of anthropogenic $\mathrm{CO}_{2}$ from fossil fuel burning and deforestation has become widely known as the Suess Effect (Keeling 1979) by analogy with a similar depletion of radiocarbon described by Suess (1953). Therefore, excluding this effect, the mean isotopic signature of the Pleistocene specimen corresponds to an isotopically lighter carbon than that in the recent record. This difference can be interpreted in terms of a higher contribution of soil-derived carbon, which agrees with the general interglacial conditions in this epoch (Ortiz et al. 2009). In fact, the prevalence of humid conditions and enhanced vegetation productivity, related also to the increased dynamics of regional karstic systems, is also supported by the speleothemic development recorded in the southeastern sector of the Iberian Ranges at the onset of the MIS 7 (Pérez-Mejías et al. 2017).

\subsection{3 $\delta^{13} \mathrm{C}$ and $\delta^{18} \mathrm{O}$ relationship}

The overall set of $\delta^{13} \mathrm{C}$ and $\delta^{18} \mathrm{O}$ values recorded in the Pleistocene samples does not show a meaningful correlation. $\delta^{13} \mathrm{C}$ and $\delta^{18} \mathrm{O}$ covariation has not been found either in present deposits of the River Piedra, and $\delta^{13} \mathrm{C}$ values only display a weak seasonal variation in the modern stromatolites (Osácar et al. 2013; Arenas et al. 2018). Although a seasonal behavior in carbon isotope composition is sometimes present (e.g., Matsuoka et al. 2001; Lojen et al. 2004; Smith et al. 2004; Liu et al. 2006), the absence of seasonal $\delta^{13} C_{\text {calcite }}$ patterns in tufas is common, caused by the number of conflicting parameters that affect the signature (Andrews et al. 1997; Lojen et al. 2004; Andrews 2006; Brasier et al. 2010; Osácar et al. 2013).

However, when values of the laminae of types A and B are analyzed separately, a meaningful positive correlation $(R=0.64, p<0.05)$ is obtained for type B laminae in 
specimen LBA-9a (which also shows the widest range in $\delta^{13} \mathrm{C}$ and $\delta^{18} \mathrm{O}$ values), and for the type A laminae in specimen LBA-9b $(R=0.69, p<0.05)$.

Positive correlation between $\delta^{13} \mathrm{C}$ and $\delta^{18} \mathrm{O}$ values have been described in some tufa deposits (e.g., Pazdur et al. 1988; Matsuoka et al. 2001; Andrews et al. 1997, 2000; Andrews 2006; Liu et al. 2006; Kano et al. 2007; Yan et al. 2017), and their environmental meaning has been widely discussed (e.g., Pazdur et al. 1988; Andrews et al. 2000; Smith et al. 2004; Cremaschi et al. 2010; Wang et al. 2014). Tufa isotope covariance may reflect climatic controls on the carbon- and oxygen-isotope composition of the related waters or may be an effect of systematic downstream variations in both isotopes, e.g. related to in-stream physicochemical processes, like evaporation or kinetic isotope effects, during tufa deposition (Smith et al. 2004; Yan et al. 2012).

In the studied Pleistocene stromatolites the observed covariation, affecting only to one kind of laminae, would most probably support an origin related with local physicochemical processes in the stream, promoting additional and variable participation of $\mathrm{CO}_{2}$ outgassing and evaporation processes in the sites, instead of reflecting climatic controls. Photosynthesis effects may also lead to an increase in $\delta^{13} \mathrm{C}$ of calcite (cf. Pentecost 2000, 2005), which should be more intense in the warm periods.

The range of $\delta^{13} \mathrm{C}$ values for the cool periods in specimen LBA-9b is similar to those in the recent stromatolite (Fig. 8), where no covariation with $\delta^{18} \mathrm{O}$ has been found. The shift in the range of $\delta^{13} \mathrm{C}$ values for the warm period laminae in specimen LBA-9a (most probably related with local evaporation processes) is small compared with the rest of examined samples (Fig. 8). These observations would support an interpretation that, even in these particular situations with the detected $\delta^{13} \mathrm{C}$ and $\delta^{18} \mathrm{O}$ covariation, calcite deposition occurred not far from isotopic equilibrium, as it was also inferred from the $\delta^{18} \mathrm{O}$ calculated $T w$. Despite the absence of $\delta^{13} \mathrm{C}$ rhythmicity, the parallelism between the evolution of $\delta^{13} \mathrm{C}$ and $\delta^{18} \mathrm{O}$ through time in both the Pleistocene and the recent stromatolites supports the use of the textural and isotopic outcomes of the tufa monitoring study to interpret climate and environmental parameters of the fossil tufa in the River Piedra context.

\subsection{Comparison with other ancient stromatolites}

There are few published studies that deal with coupled textural features and stable isotopic composition of the laminae in ancient stromatolites and oncolites aiming to decipher the depositional, hydrological and climatic conditions. Most of these studies refer to either fluvial or lacustrine carbonate systems, and marine examples are very rare. The very few published or known marine examples formed in coastal lagoons and tidal flats, generally with high salinity and involving dolomitic laminae (e.g. Paull et al. 1992; Travé Herrero 1992; Wright 1993). These facts make comparison with continental stromatolites and oncolites, in particular those of freshwater environments, more difficult because of the different and/ or more varied parameters involved in the textural features and isotopic signatures. For example, one of these studies that considered seriated isotopic studies corresponds to sub-recent lagoon environments, but the results were largely influenced by diagenetic effects and therefore their use concerning environmental conditions are blurred (Paull et al. 1992).

In fluvial systems, Brasier et al. (2010) found that the cyclic evolution of $\delta^{18} \mathrm{O}$ in a laminated tufa deposit $\sim 100 \mathrm{ka}$ (the Pleistocene, MIS 5) in Greece reflects seasonal changes in stream water temperature. However, the calculated $T w$ values underestimated the present-day seasonal range. The sharp textural changes and the shifts in $\delta^{18} \mathrm{O}$ at the lamina boundaries allowed them to conclude that the calculated $T w$ reflects only the spring and autumn stream temperatures, explaining the mismatch between expected and $\delta^{18} \mathrm{O}$-calculated temperature range. Another example from an Eemian tufa stromatolite in France (Dabkowski et al. 2015) showed abrupt $\delta^{18} \mathrm{O}$ reversals within the laminae, which were related to changes in growth rate in spring and autumn. Therefore, these studies demonstrated the utility of coupled textural and geochemical studies to infer climatic conditions at seasonal scale. The recent stromatolites in the River Piedra valley show similar behaviour, with textural features and isotopic data being more continuous (Arenas et al. 2018), and therefore reflecting more complete records, which strongly supports the use of the results obtained from this study to other examples.

Moreover, implications from the mid Pleistocene stromatolites in the River Piedra are consistent with the palaeoclimatic potential inferred from the mid Holocene dense-porous laminated tufa formed in high-altitude streams of the northern Tibetan Plateau (Mischke and Zhang 2008), which broadens the spectrum of application of this type of studies. There, annual couplets consisting of dense (thicker white) and porous (thinner dark) laminae formed, respectively, during the warm and relatively wet summer season (lower $\delta^{18} \mathrm{O}$ values), with faster deposition due to higher temperature, and during the cool and drier spring and autumn (higher $\delta^{18} \mathrm{O}$ values), with slower deposition. Interruptions are represented by sharp changes in texture and isotopic composition, which correspond to very cold conditions. These seasonal variations greatly fit the 
textural and stable isotope variations in the River Piedra and in other Quaternary examples of the Iberian Ranges (Osácar et al. 2017).

Lamination in oncolites and stromatolites that formed in older fluviolacustrine systems has been the focus of several studies. In the late Paleocene to Eocene of the Ebro Basin (northeastern part of the Iberian Peninsula), the stable isotope composition showed no significant difference between the light and the dark laminae, which was attributed to the tropical conditions of the basin by that time (Zamarreño et al. 1997). During the Late Jurassic, in the northern part of the Iberian Peninsula, microbial lamination has been the focus of textural and stable isotopic studies (Arenas et al. 2015). The cyclic and parallel variation of texture and isotopic values was interpreted as a function of temperature and precipitation acting at different time scales, in spite of the fact that there were very small differences in the $\delta^{18} \mathrm{O}$ between the light and dark laminae. Regardless, textural and isotopic variations are consistent with the results from this study.

In the case of closed lake systems, the effects of temperature on $\delta^{18} \mathrm{O}$ fractionation are variably blurred (Leng and Marshall 2004). In contrast, evaporation effects are more effective on the water $\delta^{18} \mathrm{O}$ and thus on calcite $\delta^{18} \mathrm{O}$. Therefore, the cyclic $\delta^{18} \mathrm{O}$ variation of the laminae commonly is attributed to changes in evaporation and recharge of the lake water (e.g. Talbot 1990; Frantz et al. 2014; Martín Bello et al. 2017). Frantz et al. (2014) found that lacustrine stromatolites of the Green River Formation (Eocene, USA) have strongly covariant $\delta^{13} \mathrm{C}$ and $\delta^{18} \mathrm{O}$, which is consistent with the closed character of the lake. The large-crystal laminae (fan microfabric), interpreted as abiogenic in nature, have lower $\delta^{18} \mathrm{O}$ and formed in cooler waters, when the lake was deeper. In contrast, the micrite laminae, with evidence of biogenicity, are enriched in $\delta^{18} \mathrm{O}$ and formed when the lake was shallow and warm (Frantz et al. 2014). The Pleistocene samples studied in the River Piedra valley showed similar textural features and isotopic behaviour, with the type B laminae formed in the warm periods and the type A laminae formed in the cool periods. The $\delta^{18} \mathrm{O}$ cyclicity in that river reflected the seasonal variations in $T w$, typical of hydrologically open systems, in which $\delta^{13} \mathrm{C}$ values do not parallel $\delta^{18} \mathrm{O}$ variations. Regardless of the process involved in $\delta^{18} \mathrm{O}$ signature, the textural and isotopic features of the Eocene lacustrine and the Pleistocene fluvial stromatolites are comparable on a seasonal scale, which vouch for the use of such coupled analyses to constrain highresolution climatic conditions (Martín Bello et al., work in progress). Therefore, the comparison of the results of this study with those from other ancient stromatolites greatly supports the value and broad application of the findings to other fossil examples, including those from other environmental settings.

\section{Conclusions}

1) Textural and stable-isotope variations of two Pleistocene fluvial stromatolite specimens have been studied and compared with a recent fluvial stromatolite of the same valley (River Piedra, Iberian Ranges). Both the ancient and recent deposits formed in similar sedimentary contexts: a steep cascade-barrage with fast water flow.

2) Pleistocene lamination consists of alternating thin large-crystal laminae (type A) and thick smallcrystal laminae (type B). The textural rhythmicity reflects the different growth of the microbial mats, being much smaller or even absent during the type A laminae formation. Gradual textural change from type $\mathrm{B}$ laminae to type A laminae reflects decreasing microbial activity as a result of cooling. Recent fluvial stromatolites show thickness and porosity variations comparable to the Pleistocene examples. These results confirm that large-crystal laminae reflect calcite precipitation in the absence of microbial mats, which can occur in cool conditions and/or on substrates devoid of microbial mats.

3) Both Pleistocene and modern carbonates studied here show a clear cyclicity in $\delta^{18} \mathrm{O}_{\text {calcite }}$ through consecutive laminae that is caused by temperature seasonality, therefore suggesting that each couple A $+\mathrm{B}$ represents one year. The pronounced cyclicity of $\delta^{18} \mathrm{O}_{\text {calcite }}$ indicates that the $\delta^{18} \mathrm{O}_{\text {water }}$ composition was substantially stable during the Pleistocene stromatolite formation and is evidence that stromatolite calcite was precipitated close to isotopic equilibrium, and was not significantly altered by diagenesis. The seasonal temperature range was wider than in recent stromatolite.

4) $\delta^{13} \mathrm{C}$ of Pleistocene stromatolites do not show any distinct pattern through time. However, $\delta^{13} \mathrm{C}$ correlates well with $\delta^{18} \mathrm{O}$ in some cases, remarkably in warm-period deposits of one of the specimens. This correlation may be caused by a local increase in evaporation during the warm periods and is also suggestive of photosynthesis effects on $\delta^{13} \mathrm{C}$.

5) The Pleistocene stromatolites show overall parallel evolution of $\delta^{13} \mathrm{C}_{\text {calcite }}$ and $\delta^{18} \mathrm{O}_{\text {calcite, }}$ which is also present in the recent stromatolite, except for a group of data coinciding with river discharge decrease.

6) The similarity between the isotopic behavior of Pleistocene and recent stromatolites in the River 
Piedra, along with the comparison with other ancient stromatolites, supports the extrapolation of results from the recent to the ancient stromatolites in fluvial and likely in other environments.

\section{Abbreviations}

DIC: Dissolved inorganic carbon; EPS: Extracellular polymeric substances: MIS: Marine Isotope Stage; SEM: Scanning electron microscopy; SMOW: Standard mean ocean water; Tair: Temperature of air Tw: Temperature of water; VPDB: Vienna Pee Dee Belemnite; XRD: X-ray diffraction

\section{Acknowledgements}

Our gratitude to M. Vázquez-Urbez and G. Pardo Tirapu for their scientific help. We thank the personnel of the Servicio de Preparación de Rocas y Materiales Duros and Scanning Electron Microscopy (Servicio General de Apoyo a la Investigación-SAl) of the University of Zaragoza. We are grateful to the management and staff of the Monasterio de Piedra Natural Park for facilitating our fieldwork. Dr. Stephen Kershaw and editor Xiu-Fang Hu are thanked for their pertinent comments and suggestions. Other reviewers also contributed to improve the quality of the contribution.

\section{Funding}

This study was funded by projects CGL2009-09216/CLI and CGL2013-42867 of the Spanish Government and European Regional Funds. This work fits the objectives of the research groups Geotransfer, Procesos Geoambientales y Cambio Global and Modelización Geoquímica (Aragón Government and University of Zaragoza, and European Regional Funds). The results form part of the activities of the Geotransfer scientific group (Aragón Government, Operating Program FEDER Aragón 2014-2020).

\section{Availability of data and materials}

University of Zaragoza.

\section{Authors' contributions}

CA carried out the sedimentology (field and laboratory), sampling in the field, and participated in the interpretation of results and writing the paper MCO participated in field sampling, performed the stable isotope interpretation and writing the paper. LA participated in field sampling and in the stable isotope interpretation, and writing the paper. CS contributed with field campaigns and laboratory work including sampling. All authors read and approved the final manuscript.

\section{Competing interests}

The authors declare that they have no competing interests.

\section{Publisher's Note}

Springer Nature remains neutral with regard to jurisdictional claims in published maps and institutional affiliations.

Received: 10 October 2018 Accepted: 2 January 2019

Published online: 08 March 2019

\section{References}

Affek, H.P., M. Bar-Matthews, A. Ayalon, A. Matthews, and J.M. Eiler. 2008 Glacial/interglacial temperature variations in Soreq cave speleothems as recorded by 'clumped isotope' thermometry. Geochimica et Cosmochimica Acta 72 (22): 5351-5360.

Andrews, J.E. 2006. Palaeoclimatic records from stable isotopes in riverine tufas: Synthesis and review. Earth-Science Reviews 75: 85-104.

Andrews, J.E., M. Pedley, and P.F. Dennis. 2000. Palaeoenvironmental records in Holocene Spanish tufas: A stable isotope approach in search of reliable climatic archives. Sedimentology 47 (5): 961-978.

Andrews, J.E., R. Riding, and P.F. Dennis. 1993. Stable isotopic compositions of recent freshwater cyanobacterial carbonates from the British Isles: Local and regional environmental controls. Sedimentology 40 (2): 303314.

Andrews, J.E., R. Riding, and P.F. Dennis. 1997. The stable isotope record of environmental and climatic signals in modern terrestrial microbial carbonates from Europe. Palaeogeography, Palaeoclimatology, Palaeoecology 129 (1-2): 171-189.

Anzalone, E., V. Ferreri, M. Sprovieri, and B. D'Argenio. 2007. Travertines as hydrologic archives: The case of the Pontecagnano deposits (southern Italy). Advances in Water Resources 30 (10): 2159-2175.

Arenas, C., and B. Jones. 2017. Temporal and environmental significance of microbial lamination: Insights from recent fluvial stromatolites in the river Piedra, Spain. Sedimentology 64 (6): 1597-1629.

Arenas, C., C. Osácar, C. Sancho, M. Vázquez-Urbez, L. Auqué, and G. Pardo. 2010. Seasonal record from recent fluvial tufa deposits (Monasterio de Piedra, NE Spain): Sedimentological and stable isotope data. In: H.M. Pedley, and M. Rogerson (Eds.), Tufas and speleothems: Unravelling the microbial and physical controls. Geological society special publications 336, London, pp. 119-142.

Arenas, C., M.C. Osácar, L.F. Auqué, J.E. Andrews, G. Pardo, A. Marca, L. Martín Bello, and F.J. Pérez-Rivarés. 2018. Seasonal temperatures from $\delta^{18} \mathrm{O}$ in recent Spanish tufa stromatolites: Equilibrium redux! Sedimentology 65 (5): 1611-1630.

Arenas, C., L. Piñuela, and J.C. García-Ramos. 2015. Climatic and tectonic controls on carbonate deposition in syn-rift siliciclastic fluvial systems: A case of microbialites and associated facies in the late Jurassic. Sedimentology 62: 1149-1183.

Arenas, C., M. Vázquez-Urbez, L. Auqué, C. Sancho, C. Osácar, and G. Pardo. 2014. Intrinsic and extrinsic controls of spatial and temporal variations in modern fluvial tufa sedimentation: A thirteen-year record from a semiarid environment. Sedimentology 61 (1): 90-132.

Arenas-Abad, C., M. Vázquez-Urbez, G. Pardo-Tirapu, and C. Sancho-Marcén. 2010. Fluvial and associated carbonate deposits. In Carbonates in continental settings: Facies, Environments and Processes. Developments in Sedimentology, ed. A.M. Alonso-Zarza and L.H. Tanner, vol. 61, 133-175.

Arp, G. 1995. Lacustrine bioherms, spring mounds, and marginal carbonates of the Ries-impact-crater (Miocene, southern Germany). Facies 33 (1): $35-89$

Arp, G. A Bissett, N. Brinkmann, S. Cousin, D de Beer, T. Friedl, KI. Mohr, TR Neu, A. Reimer, F. Shiraishi, E. Stackebrandt, and B. Zippel. 2010. Tufaforming biofilms of German karstwater streams: Microorganisms, exopolymers, hydrochemistry and calcification. In: H.M. Pedley, and M. Rogerson (Eds.), Tufas and speleothems: Unravelling the microbial and physical controls. Geological society special publications 336, London, pp. 83-118.

Berrendero, E., C. Arenas, P. Mateo, and B. Jones. 2016. Cyanobacterial diversity and related sedimentary facies as a function of water flow conditions: Example from the Monasterio de Piedra Natural Park (Spain). Sedimentary Geology 337: 12-28.

Böhm, F., M.M. Joachimski, W.C. Dullo, A. Eisenhauer, H. Lehnert, J. Reitner, and G. Wörheide. 2000. Oxygen isotope fractionation in marine aragonite of coralline sponges. Geochimica et Cosmochimica Acta 64 (10): 1695-1703.

Brasier, A.T, J.E. Andrews, and A.C. Kendall. 2011. Diagenesis or dire genesis? The origin of columnar spar in tufa stromatolites of Central Greece and the role of chironomid larvae. Sedimentology 58 (5): 1283-1302.

Brasier, A.T., J.E. Andrews, A.D. Marca-Bell, and P.F. Dennis. 2010 Depositional continuity of seasonally laminated tufas: Implications for $\delta^{18} \mathrm{O}$ based palaeotemperatures. Global and Planetary Change 71 (3-4): 160-167.

Capezzuoli, E., A. Gandin, and M. Pedley. 2014. Decoding tufa and travertine (fresh water carbonates) in the sedimentary record: The state of the art. Sedimentology 61 (1): 1-21.

Cerling, T.E. 1984. The stable isotopic composition of modern soil carbonate and its relationship to climate. Earth and Planetary Science Letters 71 (2): 229-240.

Cerling, T.E. 1991. Carbon dioxide in the atmosphere: Evidence from Cenozoic and Mesozoic paleosols. American Journal of Science 291 (4): $377-400$.

Chafetz, H.S., N.M. Utech, and S.P. Fitzmaurice. 1991. Differences in the $\delta^{18} \mathrm{O}$ and $\delta^{13} \mathrm{C}$ signatures of seasonal laminae comprising travertine stromatolites. Journal of Sedimentary Petrology 61 (6): 1015-1028.

Craig, H. 1965. The measurement of oxygen isotope palaeotemperatures. In Stable Isotopes in Oceanographic Studies and Palaeotemperatures, ed. E. Tongiorgi, 161-182. Pisa: Consiglio Nazionale delle Ricerche, Laboratorio di Geologia Nucleare. 
Cremaschi, M., A. Zerboni, C. Spötl, and F. Felletti. 2010. The calcareous tufa in the Tadrart Acacus Mt. (SW Fezzan, Libya): An early Holocene palaeoclimate archive in the Central Sahara. Palaeogeography, Palaeoclimatology, Palaeoecology 287: 81-94.

D'Argenio, B., and V. Ferreri. 1988. Ambienti di deposizione e litofacies dei travertine quaternary dell'Italia centro-meridionale. Memoria della Società Geologica Italiana 41: 861-868.

Dabkowski, J., S.H. Royle, P. Antoine, A. Marca-Bell, and J.E. Andrews. 2015. High resolution $\delta^{18} \mathrm{O}$ seasonality record in a French Eemian tufa stromatolite (Caours, Somme Basin). Palaeogeography, Palaeoclimatology, Palaeoecology 438: 277-284.

Deines, P. 1980. The isotopic composition of reduced organic carbon. In Handbook of Environmental Isotope Geochemistry. 1. The Terrestrial Environment, ed. A.P. Fritz and J.Ch. Fontes, 329-406. Elsevier, Amsterdam.

Ford, T.D., and H.M. Pedley. 1996. A review of tufa and travertine deposits of the world. Earth-Science Reviews 41 (3-4): 117-175.

Frantz, C.M., V.A. Petryshyn, P.J. Marenco, A. Tripati, W.M. Berelson, and F.A. Corsetti. 2014. Dramatic local environmental change during the early Eocene climatic optimum detected using high resolution chemical analyses of Green River formation stromatolites. Palaeogeography, Palaeoclimatology, Palaeoecology 405: 1-15.

Friedli, H., H. Lötscher, H. Oeschger, U. Siegenthaler, and B. Stauffer. 1986. Ice core record of the ${ }^{13} \mathrm{C} /{ }^{12} \mathrm{C}$ ratio of atmospheric $\mathrm{CO}_{2}$ in the past two centuries. Nature 324: 237-238.

Garnett, E.R., J.E. Andrews, R.C. Preece, and P.F. Dennis. 2004. Climatic change recorded by stable isotopes and trace elements in a British Holocene tufa. Journal of Quaternary Science 19 (3): 251-262.

Golubic, S. 1976. Chapter 4.1 organisms that build stromatolites. In Stromatolites. Developments in Sedimentology, Volume 20, ed. M.R. Walter, 113-126. Amsterdam: Elsevier.

Hori, M., T. Kawai, J. Matsuoka, and A. Kano. 2009. Intra-annual perturbations of stable isotopes in tufas: Effects of hydrological processes. Geochimica et Cosmochimica Acta 73 (6): 1684-1695.

Kalkowsky, E. 1908. Oolith und stromatolith im Nord-deutschen Buntsandstein. Zeitschrift der Deutschen Geologischen Gesellschaft 60: 68-125.

Kano, A., R. Hagiwara, T. Kawai, M. Hori, and J. Matsuoka. 2007. Climatic conditions and hydrological change recorded in a high-resolution stable-isotope profile of a recent laminated tufa on a subtropical island, southern Japan. Journal of Sedimentary Research 77 (1): 59-67.

Keeling, C.D. 1979. The Suess effect: ${ }^{13}$ Carbon- ${ }^{14}$ Carbon interrelations. Environment International 2 (4): 229-300.

Killops, S., and V. Killops. 2005. Introdution to Organic Geochemistry. 2nd ed. Blackwell Publishing Ltd., United Kingdom.

Kim, S.-T., and J.R. O'Neil. 1997. Equilibrium and nonequilibrium oxygen isotope effects in synthetic carbonates. Geochimica et Cosmochimica Acta 61 (16): 3461-3475.

Leng, M.J., and J.D. Marshall. 2004. Palaeoclimate interpretation of stable isotope data from lake sediment archives. Quaternary Science Reviews 23 (7): 811-831.

Lisiecki, L.E., and M.E. Raymo. 2005. A Pliocene-Pleistocene stack of 57 globally distributed benthic $\delta^{18} \mathrm{O}$ records. Paleoceanography 20 (1): PA1003.

Liu, Z.H., H.C. Li, C.F. You, N.J. Wan, and H.L. Sun. 2006. Thickness and stable isotopic characteristics of modern seasonal climate-controlled sub-annual travertine laminas in a travertine-depositing stream at Baishuitai, SW China: Implications for paleoclimate reconstruction. Environmental Geology 51 (2): 257-265.

Lojen, S., T. Dolenec, B. Vokal, N. Cukrov, G. Miheľ̌ić, and W. Papesch. 2004. $\mathrm{C}$ and $\mathrm{O}$ stable isotope variability in recent freshwater carbonates (river Krka, Croatia). Sedimentology 51 (2): 361-375.

Manzo, E., E. Perri, and M.E. Tucker. 2012. Carbonate deposition in a fluvial tufa system: Processes and products (Corvino Valley - Southern Italy). Sedimentology 59 (2): 553-577.

Martín Bello, L., C. Arenas Abad, and A.M. Alonso Zarza. 2017. Preliminary interpretation of the stable-isotope composition in lacustrine stromatolites of the sierra de Alcubierre (Miocene, Ebro Basin, Spain). Geogaceta 61: 171-174.

Matsuoka, J., A. Kano, T. Oba, T. Watanabe, S. Sakai, and K. Seto. 2001. Seasonal variation of stable isotopic compositions recorded in a laminated tufa, SW Japan. Earth and Planetary Science Letters 192 (1): $31-44$.
Merz-Preiß, M., and R. Riding. 1999. Cyanobacterial tufa calcification in two freshwater streams: Ambient environment, chemical thresholds and biological processes. Sedimentary Geology 126: 103-124.

Mischke, S., and C.J. Zhang. 2008. A laminated tufa carbonate from the mid Holocene of the Qilian Mountains and its potential for palaeoclimate inferences. Episodes 31 (4): 401-407.

O'Brien, G.R., D.S. Kaufman, W.D. Sharp, V. Atudorei, R.A. Parnell, and L.J. Crossey. 2006. Oxygen isotope composition of annually banded modern and mid-Holocene travertine and evidence of paleomonsoon floods, grand canyon, Arizona, USA. Quaternary Research 65 (3): 366-379.

Ortiz, J.E., T. Torres, A. Delgado, E. Reyes, and A. Díaz-Bautista. 2009. A review of the Tagus river tufa deposits (Central Spain): Age and palaeoenvironmental record. Quaternary Science Reviews 28 (9): 947-963.

Osácar, M.C., C. Arenas, L. Auqué, C. Sancho, G. Pardo, and M. Vázquez-Urbez. 2016. Discerning the interactions between environmental parameters reflected in $\delta^{13} \mathrm{C}$ and $\delta^{18} \mathrm{O}$ of recent fluvial tufas: Lessons from a Mediterranean climate region. Sedimentary Geology 345: 126-144.

Osácar, M.C., C. Arenas, M. Vázquez-Urbez, C. Sancho, L.F. Auqué, and G. Pardo. 2013. Environmental factors controlling the $\delta^{13} \mathrm{C}$ and $\delta^{18} \mathrm{O}$ variations of recent fluvial tufas: A 12-year record from the Monasterio de Piedra Natural Park (NE Iberian Peninsula). Journal of Sedimentary Research 83 (4): 309-322.

Osácar Soriano, M.C., C. Arenas Abad, C. Sancho Marcén, G. Pardo Tirapu, and L. Martín Bello. 2017. Stable-isotope changes in tufa stromatolites of the quaternary Añamaza fluvial system (Iberian ranges, Spain). Geogaceta 61: 167-170.

Paull, C.K., A.C. Neumann, B. Bebout, V. Zabielski, and W. Showers. 1992. Growth rate and stable isotopic character of modern stromatolites from San Salvador, Bahamas. Palaeogeography, Palaeoclimatology, Palaeoecology 95 (3-4): 335-344.

Pazdur, A., M.F. Pazdur, L. Starkel, and J. Szulc. 1988. Stable isotopes of Holocene calcareous tufa in southern Poland as paleoclimatic indicators. Quaternary Research 30 (2): 177-189.

Pedley, H.M. 1990. Classification and environmental models of cool freshwater tufas. Sedimentary Geology 68 (1): 143-154.

Pedley, M. 2014. The morphology and function of thrombolitic calcite precipitating biofilms: A universal model derived from freshwater mesocosm experiments. Sedimentology 61 (1): 22-40.

Peña, J.L., C. Sancho, C. Arenas, L. Auqué, L.A. Longares, M.V. Lozano, A. Meléndez, C. Osácar, G. Pardo, and M. Vázquez-Urbez. 2014. Las tobas cuaternarias en el sector aragonés de la Cordillera Ibérica. In Las tobas en España, ed. J.A. González Martín and M.J. González Amuchastegui, 159-172. Badajoz: Sociedad Española de Geomorfología.

Pentecost, A. 1978. Blue-green algae and freshwater carbonate deposits. Proceedings of the Royal Society of London. Series B, Biological Sciences 200 (1138): 43-61.

Pentecost, A. 1987. Growth and calcification of the freshwater cyanobacterium Rivularia haematites. Proceedings of the Royal Society of London. Series B, Biological Sciences 232 (1266): 125-136.

Pentecost, A. 1988. Growth and calcification of the cyanobacterium Homoeothris crustacea. Microbiology 134 (10): 2665-2671.

Pentecost, A. 2000. A note on the stable carbon isotope composition of bryophytes in calcareous aquatic habits and its relationship to carbon dioxide assimilation. Journal of Bryology 22 (1): 13-15.

Pentecost, A. 2005. Travertine. Berlin: Springer-Verlag.

Pérez-Mejías, C., A. Moreno, C. Sancho, M. Bartolomé, H. Stoll, I. Cacho, H. Cheng, and R.L. Edwards. 2017. Abrupt climate changes during termination III in southern Europe. Proceedings of the National Academy of Sciences of the United States of America 114 (38): 10047-10052.

Riding, R. 1991. Classification of microbial carbonates. In Calcareous algae and stromatolites, ed. R. Riding, 21-51. Berlin: Springer-Verlag.

Riding, R. 2000. Microbial carbonates: The geological record of calcified bacterial-algal mats and biofilms. Sedimentology 47 (s1): 179-214.

Rodríguez-Berriguete, Á., A.M. Alonso-Zarza, R. Martín-García, and M.C. Cabrera. 2018. Sedimentology and geochemistry of a human-induced tufa deposit: Implications for palaeoclimatic research. Sedimentology. https://doi.org/10.1111/sed.12464.

Romanek, C.S., E.L. Grossman, and J.W. Morse. 1992. Carbon isotopic fractionation in synthetic aragonite and calcite: Effects of temperature and precipitation rate. Geochimica et Cosmochimica Acta 56 (1): 419-430. 
Sancho, C., C. Arenas, M. Vázquez-Urbez, G. Pardo, M.V. Lozano, J.L. PeñaMonné, J. Hellstrom, J.E. Ortiz, M.C. Osácar, L. Auqué, and T. Torres. 2015. Climatic implications of the quaternary fluvial tufa record in the NE Iberian Peninsula over the last $500 \mathrm{ka}$. Quaternary Research 84 (3): 398-414.

Smith, J.R., R. Giegengack, and H.P. Schwarcz. 2004. Constraints on Pleistocene pluvial climates through stable-isotope analysis of fossilspring tufas and associated gastropods, Kharga oasis, Egypt. Palaeogeography, Palaeoclimatology, Palaeoecology 206 (1-2): 157-175.

Suess, H.E. 1953. Natural radiocarbon and the rate of exchange of carbon dioxide between the atmosphere and the sea. In Nuclear processes in geologic settings, ed. W. Aldrich, 52-56. Chicago: University of Chicago Press.

Talbot, M.R. 1990. A review of the palaeohydrological interpretation of carbon and oxygen isotopic ratios in primary lacustrine carbonates. Chemical Geology, Isotope Geosciences Section 80: 261-279.

Travé Herrero, A. 1992. Sedimentologia, petrologia i geoquímica (elements traça I isòtops) dels estromatòlits de la Conca Eocena Sudpirenenca [Unpublished PhD. Thesis]. Universitat de Barcelona, Spain.

Usdowski, E., J. Hoefs, and G. Menschel. 1979. Relationship between ${ }^{13} \mathrm{C}$ and ${ }^{18} \mathrm{O}$ fractionation and changes in major element composition in a recent calcite-depositing spring - A model of chemical variations with inorganic $\mathrm{CaCO}_{3}$ precipitation. Earth and Planetary Science Letters 42 (2): 267-276.

Vázquez-Urbez, M., C. Arenas, and G. Pardo. 2012. A sedimentary facies model for stepped, fluvial tufa systems in the Iberian range (Spain): The quaternary Piedra and Mesa valleys. Sedimentology 59 (2): 502-526.

Vázquez-Urbez, M., C. Arenas, C. Sancho, C. Osácar, L. Auqué, and G. Pardo. 2010. Factors controlling present-day tufa dynamics in the Monasterio de Piedra Natural Park (Iberian range, Spain): Depositional environmental settings, sedimentation rates and hydrochemistry. International Journal of Earth Sciences 99 (5): 1027-1049.

Vázquez-Urbez, M., G. Pardo, C. Arenas, and C. Sancho. 2011. Fluvial diffluence episodes reflected in the Pleistocene tufa deposits of the river Piedra (Iberian range, NE Spain). Geomorphology 125 (1): 1-10.

Vera, J.A., ed. 2004. Geología de España. Madrid: SGE-IGME.

Wang, H.J., H. Yan, and Z.H. Liu. 2014. Contrasts in variations of the carbon and oxygen isotopic composition of travertines formed in pools and a ramp stream at Huanglong ravine, China: Implications for paleoclimatic interpretations. Geochimica et Cosmochimica Acta 125: 34-48.

Wright, D.T. 1993. Carbon isotope geochemistry of Cambrian stromatolites, NW Scotland. In Studies on Fossil Benthic Algae. Bollettino della Societa Paleontologica Italiana, Special, ed. F. Barattolo, P. De Castro, and M. Parente, vol. 1, 415-420.

Yan, H., Z.H. Liu, and H.L. Sun. 2017. Effect of in-stream physicochemical processes on the seasonal variations in $\delta^{13} \mathrm{C}$ and $\delta^{18} \mathrm{O}$ values in laminated travertine deposits in a mountain stream channel. Geochimica et Cosmochimica Acta 202: 179-189.

Yan, H., H.L. Sun, and Z.H. Liu. 2012. Equilibrium vs. kinetic fractionation of oxygen isotopes in two low-temperature travertine-depositing systems with differing hydrodynamic conditions at Baishuitai, Yunnan, SW China. Geochimica et Cosmochimica Acta 95: 63-78.

Zamarreño, I., P. Anadón, and R. Utrilla. 1997. Sedimentology and isotopic composition of upper Palaeocene to Eocene non-marine stromatolites, eastern Ebro Basin, NE Spain. Sedimentology 44 (1): 159-176.

\section{Submit your manuscript to a SpringerOpen ${ }^{\circ}$ journal and benefit from:}

- Convenient online submission

- Rigorous peer review

- Open access: articles freely available online

- High visibility within the field

- Retaining the copyright to your article

Submit your next manuscript at $\boldsymbol{\nabla}$ springeropen.com 